\title{
Article \\ Topical Spray of dsRNA Induces Mortality and Inhibits Chilli Leaf Curl Virus Transmission by Bemisia tabaci Asia II 1
}

\author{
Prosenjit Chakraborty (1) and Amalendu Ghosh (1)* \\ Insect Vector Laboratory, Advanced Centre for Plant Virology, Indian Agricultural Research Institute, \\ New Delhi 110012, India; nbu.prosen@yahoo.in \\ * Correspondence: amalendu.ghosh@icar.gov.in or amal4ento@gmail.com
}

check for updates

Citation: Chakraborty, P.; Ghosh, A. Topical Spray of dsRNA Induces Mortality and Inhibits Chilli Leaf Curl Virus Transmission by Bemisia tabaci Asia II 1. Cells 2022, 11, 833.

https://doi.org/10.3390/ cells11050833

Academic Editors: Ahmed Hadidi, Henryk Hanokh Czosnek and Suleyman Allakhverdiev

Received: 28 December 2021 Accepted: 18 February 2022 Published: 28 February 2022

Publisher's Note: MDPI stays neutral with regard to jurisdictional claims in published maps and institutional affiliations.

Copyright: (C) 2022 by the authors. Licensee MDPI, Basel, Switzerland. This article is an open access article distributed under the terms and conditions of the Creative Commons Attribution (CC BY) license (https:// creativecommons.org/licenses/by/ $4.0 /)$.

\begin{abstract}
Chilli leaf curl virus (ChiLCV; genus: Begomovirus), transmitted by Bemisia tabaci (Gennadius) (Hemiptera: Aleyrodidae) in a persistent-circulative manner, is a major constraint in chilli production. The present study demonstrates for the first time that a topical spray of naked double-stranded RNA (dsRNA) on chilli plants causes mortality and inability to acquire and transmit ChiLCV in $B$. tabaci. dsRNA targeting heat shock protein 70 (hsp70) and fasciclin 2 (fas2) of B. tabaci Asia II 1 was first assessed under controlled conditions through oral delivery. Hsp70 and fas 2 dsRNA resulted in up to $82.22 \%$ and $72 \%$ mortality of B. tabaci and around 12.4- and 8.5-fold decreases in mRNA levels, respectively, $24 \mathrm{~h}$ post-ingestion. ChiLCV copies in hsp70 dsRNA-fed B. tabaci steadily decreased with an increase in dsRNA concentration and were undetectable at a higher concentration of dsRNA. However, ChiLCV copies significantly increased in fas2 dsRNA-fed B. tabaci. Transmission of ChiLCV by $B$. tabaci was completely inhibited post- $24 \mathrm{~h}$ feeding on $h s p 70$ dsRNA at $3 \mu \mathrm{g} / \mathrm{mL}$. Naked $h s p 70$ dsRNA was topically sprayed on ChiLCV-infected chilli plants like an insecticide. $67.77 \%$ mortality of B. tabaci, 4.6-fold downregulation of $h s p 70 \mathrm{mRNA}$, and $1.34 \times 10^{15}$-fold decreased ChiLCV copies in B. tabaci were recorded when adults were exposed to the dsRNA-treated plants under semi-field conditions. Foliar application of naked dsRNA reduced the ChiLCV transmission by $75 \%$ without any visible symptoms in the inoculated plants. A total of 2 consecutive sprays of dsRNA provided significant protection to $B$. tabaci for up to 20 days under semi-field conditions.
\end{abstract}

Keywords: silverleaf whitefly; begomovirus; RNAi; topical application; heat shock protein 70; fasciclin 2; virus transmission; virus-vector relationship

\section{Introduction}

Silverleaf whitefly [Bemisia tabaci (Gennadius), Hemiptera: Aleyrodidae] is a phloemfeeding hemipteran insect that has been reported to infest over 600 plant species worldwide [1-3]. B. tabaci has been considered a complex of at least 46 morphologically indistinguishable cryptic species [4-6]. B. tabaci adults are about $1 \mathrm{~mm}$ long with small triangular-shaped bodies. The body is yellowish with distinct hyaline wings dusted with white powdery wax. Adults $B$. tabaci can be distinguished from other whiteflies by the position in which the wings are held over the body. The wings are held close to the body and tent-like in B. tabaci. It sucks phloem sap, leaving the affected plants extremely weak, and secretes a honeydew onto the surface of the leaves that promotes the growth of sooty mold fungus [7]. Besides direct damage caused by feeding, B. tabaci transmits more than a hundred begomoviruses, carlaviruses, criniviruses, cytorhabdoviruses, ipomoviruses, poleroviruses, and torradoviruses ([8-16]. Among them, begomoviruses represent 90\% of the viruses transmitted by B. tabaci. Begomovirus species have become widespread in Central America, the Dominican Republic, Israel, Mexico, Trinidad, and across South East Asia, including Cambodia, Indonesia, India, and Thailand [17]. These viruses can cause an estimated yield loss of 50-90\% in tomatoes and other crops, including beans, cassava, chilli, cotton, cucurbits, eggplant, papaya, and potatoes $[18,19]$. 
Chilli (Capsicum annum L., family Solanaceae) is one of the economically important crops produced in tropical and sub-tropical countries [20]. Chilli leaf curl virus (ChiLCV, genus Begomovirus, family Geminiviridae) is a major constraint of chilli production, causing annual losses of about USD 15 billion [21]. ChiLCV is a monopartite begomovirus that contains one circular, single-stranded DNA-A component of $2.7 \mathrm{~kb}$ in size. ChiLCV is transmitted by B. tabaci in a persistent-circulative manner. Capsicum spp. are the primary hosts for ChiLCV, but it also infects tomato and amaranth [22,23]. ChiLCV has been responsible for several epidemics in India and Sri Lanka [24,25]. The disease is typically manifested in the infected plants as upward curling, puckering, bunching of leaves, blistering of interveinal areas, thickening, and swelling of the veins, shortening of internodes and petioles, and stunting of the whole plant. The leaves become smaller and severely affected plants produce fewer and deformed fruits. Yield losses of 20-50\% have been recorded in chilli [26], which may rise to $100 \%$ in the case of simultaneous infestation with thrips and mites [27]. Control options for ChiLCV and B. tabaci are very limited as insecticides continue to lose their efficacy due to the emergence of insecticide-resistant $B$. tabaci populations. Besides, insecticides adversely affect the environment and human health. Considering the continued lack of consumer acceptance, transgenic plant technology is not a feasible strategy. In recent years, RNA interference (RNAi) has shown promise in the management of insect pests and plant viruses. Double-stranded RNA (dsRNA), upon entering the host cell, is processed by the Dicer enzyme and, in association with RNA-induced silencing complex (RISC), cleaves the targeted mRNA [28]. Interrupting the interrelationship between B. tabaci and begomovirus using RNAi is a promising approach.. For successful persistent-circulative transmission, the begomovirus particles need to cross the midgut barrier of $B$. tabaci to circulate in hemolymph and reach the primary salivary glands $[29,30]$. Several proteins at the midguts of $B$. tabaci, such as heat shock proteins (Hsp), cyclophilins, peptidoglycan recognition protein, and a midgut protein, are known to interact with begomovirus coat protein (CP) for successful internalization [31-34]. RNA-Seq of $B$. tabaci in response to begomoviruses revealed significant upregulations of $h s p 70$, fasciclin 2 (fas2), and several other transcripts [31,35]. In gene regulatory network analyses, these genes were enriched with higher degrees of interactions. The same trend was recorded in the mRNA expression in reverse transcriptase quantitative real-time PCR (RT-qPCR) post-exposure to ChiLCV [35]. Although host cellular chaperones like Hsp70, along with other cochaperones play an important role in several cellular processes, host immunity, and stress responses [36], $h s p 70$ has been reported to be associated with begomovirus transmission by B. tabaci [31]. Neural cell adhesion molecule (NCAM) orthologues in B. tabaci like fas 2 function in synaptic development and growth [37,38]. Besides, NCAM molecules are known as receptors in virus replication [39]. The purpose of the present study is to validate the functions of B. tabaci hsp70 and fas 2 in ChiLCV transmission using RNAi and explore the potentiality to use them as novel genetic tools for pest management.

Although several potential RNAi targets were identified for insects, including $B$. tabaci [40-43], most of those studies were conducted under controlled experimental conditions, and their efficacy under field conditions is limited. Rapid degradation of dsRNA in the extracellular environment and lack of reliable dsRNA delivery technique limits its applicability under field conditions. The objective of the present study was to induce resistance against $B$. tabaci and ChiLCV by spray-on application of dsRNA. In the present study, B. tabaci hsp 70 and fas 2 were silenced and resultant effects in mortality and virus transmission were reported. For the first time, the efficacy of spray-on application of naked dsRNA against a hemipteran insect was demonstrated under semi-field conditions. The outcomes of the study provide a novel, eco-friendly option for protection against $B$. tabaci as well as ChiLCV, which can reduce economic losses caused by the virus-vector complex. 


\section{Materials and Methods}

\subsection{Whitefly Population}

A homogeneous isofemale line of $B$. tabaci was raised from a single adult female and has been maintained on eggplants (var. Navkiran, Mahyco) at the Advanced Centre for Plant Virology, Indian Agricultural Research Institute (IARI), New Delhi, since 2015. The population was characterized by sequencing the mitochondrial cytochrome oxidase subunit I (mtCOI) gene (Table 1). The genotype or cryptic species of the $B$. tabaci population was confirmed based on Bayesian Inference phylogeny, considering a genetic divergence cutoff of $4 \%$ as described by Rehman et al. [6]. The population was maintained under controlled environmental conditions at $28 \pm 2{ }^{\circ} \mathrm{C}, 60 \pm 10 \%$ relative humidity, and a $16 \mathrm{~h}$ light- $8 \mathrm{~h}$ dark photoperiod.

\subsection{Virus Culture}

The inoculum of ChiLCV was collected from a pure culture maintained at the Advanced Centre for Plant Virology, IARI, New Delhi, India. ChiLCV was maintained in chilli (var. Preeti, Nunhems) by B. tabaci inoculation under insect-proof conditions. The identity of the virus was further confirmed by amplifying the DNA-A component in PCR with primer pairs Begomo F and Begomo R [44] (Table 1) and sequencing.

\subsection{Designing and Synthesis of dsRNA}

For the selection of dsRNA fragments, complete gene sequences of B. tabaci hsp70 (Accession Nos. HM367079, HM013712, EU934240, HM013709) and fas2 (Accession No. XM_019049173) were downloaded from NCBI. The conserved sequences of the $h s p 70$ and fas2 genes were analyzed in siRNA Wizard 3.1, Invivogen. The segments showing potential siRNA-forming regions were tested for cross-reactivity with other organisms like Homo sapiens (chromosomes, unplaced and unlocalized scaffolds), Mus musculus (chromosomes, unplaced and unlocalized scaffolds), Aves (taxid:8782), Lepidoptera (taxid:7088), Hymenoptera (taxid:7399), Formicidae (taxid:36668), and plants (taxid:3193) in NCBI using BLAST analysis. The region specific to $B$. tabaci with no cross-reactivity with other organisms was finally selected for synthesis of dsRNA.

Primers targeting the dsRNA segment were designed in NCBI primer blast (https: / / www.ncbi.nlm.nih.gov / tools / primer-blast/ (Accessed on 4 June 2021) (Table 1). The primers AG137F-AG138R (for $h s p 70$ ) and AG283F-AG284R (for fas2) were validated in a gradient PCR. The dsRNA stretches were amplified from isofemale $B$. tabaci Asia II 1 DNA in PCR with initial denaturation at $94{ }^{\circ} \mathrm{C}$ for $5 \mathrm{~min}, 30$ cycles of $94{ }^{\circ} \mathrm{C}$ for $30 \mathrm{~s}$, $56{ }^{\circ} \mathrm{C}$ for $30 \mathrm{~s}$, and $72{ }^{\circ} \mathrm{C}$ for $30 \mathrm{~s}$ and a final extension step at $72{ }^{\circ} \mathrm{C}$ for $10 \mathrm{~min}$. The PCR products were cloned into an L4440 plasmid vector between two T7 promoters. The recombinant plasmids were transformed into RNase III mutant Escherichia coli HT115 cells. Total RNA from the recombinant E. coli HT115 cells was extracted using Trizol reagent (Invitrogen, CA, USA) following the manufacturer's protocol, and dsRNA was purified following Ahn et al. [45] with modifications. In brief, the recombinant E. coli HT115 cells were incubated for $12 \mathrm{~h}$ with continuous shaking at $37^{\circ} \mathrm{C}$ followed by induction of T7 promoter with $1 \mathrm{M}$ isopropyl- $\beta$-D-1-thiogalactopyranoside (IPTG). The bacterial cells were harvested in a $1.5 \mathrm{~mL}$ microcentrifuge tube by centrifugation at $10,000 \times g$ for $5 \mathrm{~min}$ and resuspended in $1 \mathrm{~mL}$ Trizol. The cell suspension was mixed by vortexing and kept at room temperature for $5 \mathrm{~min}$. The cell suspension was mixed with $200 \mu \mathrm{L}$ chloroform, vortexed for $<10 \mathrm{~s}$, and incubated at room temperature for $10 \mathrm{~min}$. The mixture was then centrifuged at $16,000 \times g$ for $10 \mathrm{~min}$ at $4{ }^{\circ} \mathrm{C}$. The upper clear aqueous phase was transferred to a fresh tube and 0.8 volume of ice-chilled isopropanol was added. The solution was mixed properly and incubated at $4{ }^{\circ} \mathrm{C}$ for $10 \mathrm{~min}$. The mixture was again centrifuged at $16,000 \times g$ for $10 \mathrm{~min}$ at $4{ }^{\circ} \mathrm{C}$, and the supernatant was discarded. The pellet was washed with $70 \%$ ethanol, air-dried, and resuspended in $30 \mu \mathrm{L}$ nuclease-free water. Total RNA isolated from recombinant E. coli HT115 cells was mixed with 1X RNA loading dye (Thermo Fisher Scientific, MA, USA), heated at $70{ }^{\circ} \mathrm{C}$ for $5 \mathrm{~min}$, and visualized on $2 \%$ agarose gel 
stained with GoodView (BR Biochem, New Delhi, India). The total RNA was then treated with 1 unit of DNase I, RNase-free (Thermo Fisher Scientific) and 1 unit of RNase A, DNase-, and protease-free (Thermo Fisher Scientific) in the presence of $500 \mathrm{mM}$ sodium chloride and incubated for $1 \mathrm{hr}$ at $37^{\circ} \mathrm{C}$ to eliminate the DNA and single-stranded RNA contaminants. The enzymes were inactivated by chloroform extraction, and the remaining dsRNA was resuspended in nuclease-free water. The purified dsRNA was quantified in a spectrophotometer (NanoDrop 2000, Thermo Fisher Scientific), and the integrity of the specific dsRNA was confirmed on $2 \%$ native agarose gel stained with GoodView and visualized in a gel documentation system (Maestrogen, Xiangshan District, Taiwan).

Table 1. Primers used in the study.

\begin{tabular}{|c|c|c|c|c|c|c|}
\hline Primer Name & Primer Sequence $\left(5^{\prime}-3^{\prime}\right)$ & Amplicon Size & $\begin{array}{c}\text { Annealing } \\
\text { Temperature in } \\
\text { PCR/Real- } \\
\text { Time } \\
\text { PCR }\end{array}$ & Amplified Region & Purpose & Reference \\
\hline C1-J-2195 & TTGATTTTTTGGTCATCCAGAAGT & \multirow{2}{*}{$860 \mathrm{bp}$} & \multirow{2}{*}{$53^{\circ} \mathrm{C}$} & \multirow{2}{*}{ B. tabaci mtCOI } & \multirow{2}{*}{$\begin{array}{l}\text { Detection of } B \text {. } \\
\text { tabaci cryptic } \\
\text { species }\end{array}$} & \multirow{2}{*}{ [46] } \\
\hline L2-N-3014 & TCCAATGCACTAATCTGCCATATTA & & & & & \\
\hline Begomo F & ACGCGTGCCGTGCTGCTGCCCCCATTGTCC & \multirow{2}{*}{$2.7 \mathrm{~kb}$} & \multirow{2}{*}{$57^{\circ} \mathrm{C}$} & \multirow{2}{*}{ Begomovirus DNA-A } & \multirow{2}{*}{$\begin{array}{l}\text { Detection of } \\
\text { begomovirus }\end{array}$} & \multirow{2}{*}{ [44] } \\
\hline Begomo R & ACGCGTATGGGCTGYCGAAGTTSAGAC & & & & & \\
\hline AG137F & TCAAAGAACATTTTTGTGCTACT & \multirow{2}{*}{$128 \mathrm{bp}$} & \multirow{2}{*}{$56^{\circ} \mathrm{C}$} & \multirow{2}{*}{$\begin{array}{l}\text { B. tabaci hsp } 70 \\
\text { dsRNA }\end{array}$} & \multirow{2}{*}{$\begin{array}{l}\text { dsRNA } \\
\text { synthesis }\end{array}$} & \multirow{2}{*}{ This study } \\
\hline AG138R & GACCATTGTCTAGGTCTTCATTT & & & & & \\
\hline AG283F & CTGGTGTTTTGACAATCGAC & \multirow{2}{*}{$150 \mathrm{bp}$} & \multirow{2}{*}{$56^{\circ} \mathrm{C}$} & \multirow{2}{*}{ B. tabaci fas 2 dsRNA } & \multirow{2}{*}{$\begin{array}{l}\text { dsRNA } \\
\text { synthesis and } \\
\text { RT-qPCR }\end{array}$} & \multirow{2}{*}{ This study } \\
\hline AG284R & TGATTATGCCTTCTTCCGTC & & & & & \\
\hline AG177F & ACATGGAAAAGATCTGGCAT & \multirow{2}{*}{$121 \mathrm{bp}$} & \multirow{2}{*}{$56^{\circ} \mathrm{C}$} & \multirow{2}{*}{ B. tabaci $\beta$-actin } & \multirow{2}{*}{ RT-qPCR } & \multirow{2}{*}{ This study } \\
\hline AG178R & TGAGTCATCTTTTCACGGTT & & & & & \\
\hline AG204F & GTCAATGATTGCAGTAAGCC & \multirow{2}{*}{$105 \mathrm{bp}$} & \multirow{2}{*}{$56^{\circ} \mathrm{C}$} & \multirow{2}{*}{ B. tabaci hsp 70} & \multirow{2}{*}{ RT-qPCR } & \multirow{2}{*}{ This study } \\
\hline AG205R & TTCCCTCATTTTCGTAAGCA & & & & & \\
\hline AG149F & TGAACAGGCCCATGAACAG & \multirow{2}{*}{$290 \mathrm{bp}$} & \multirow{2}{*}{$53^{\circ} \mathrm{C}$} & \multirow{2}{*}{$\begin{array}{l}\text { ChiLCV coat } \\
\text { protein }\end{array}$} & \multirow{2}{*}{$\begin{array}{l}\text { qPCR and } \\
\text { ChiLCV } \\
\text { detection }\end{array}$} & \multirow{2}{*}{ [47] } \\
\hline AG150R & ACGGACAAGGAAAAACATCAC & & & & & \\
\hline
\end{tabular}

\subsection{Bioassay of dsRNA through Artificial Feeding under Controlled Conditions}

The purified $h s p 70$ and fas 2 dsRNA were individually and orally delivered to $B$. tabaci adults following the method of Upadhyay et al. [40] with modifications. In brief, an artificial diet was prepared by mixing $20 \%$ sucrose and $5 \%$ yeast extract in sterile distilled water and autoclaved. The artificial diet was supplemented with $1.0,2.0$, and $3.0 \mu \mathrm{g} / \mathrm{mL}$ of dsRNA and sandwiched between 2 layers of UV-sterilized stretched Parafilm M membranes on the open mouth of a $15 \mathrm{~mL}$ cylindrical pet bottle $(3.5 \mathrm{~cm}$ diameter and $16 \mathrm{~cm}$ height). A hole was made on the wall of the bottle and covered with muslin cloth for ventilation. A batch of 30 adults of B. tabaci was released in each bottle to feed on the dsRNA mixed with the artificial diet for $24 \mathrm{~h}$. Sterile distilled water instead of dsRNA was served as control. After $24 \mathrm{~h}$ of feeding, percent mortality was calculated and compared with untreated control. Three replicates for each concentration were maintained and repeated twice. The mean mortalities in each treatment were corrected by normalizing mortality in the control set. Mean differences among the categories were separated by Tukey's test at a confidence interval of $95 \%$ using XLSTAT 2014.5.03. The surviving $B$. tabaci from several such replicates were used for determining the relative expression of $h s p 70$ and fas 2 mRNA and assessing the ChiLCV acquisition and transmission efficiency post-dsRNA feeding as described below.

\subsection{Estimating Relative Expression of hsp70 and fas $2 \mathrm{mRNA}$}

Relative expression of B. tabaci hsp70 mRNA post-dsRNA exposure was estimated by RT-qPCR assay following the $2^{-\Delta \Delta C}$ Tethod [48]. The $\beta$-actin gene served as endogenous control. The primer pairs (AG204F-AG205R for hsp70; AG283F-AG284R for fas2; and AG177F-AG178R for $\beta$-actin) used in RT-qPCR are listed in Table 1. After $24 \mathrm{~h}$ of has70 
and fas 2 dsRNA feeding at 1.0, 2.0, and $3.0 \mu \mathrm{g} / \mathrm{mL}$ as described above, the surviving $B$. tabaci were collected from each of the treatments separately. About 30 surviving $B$. tabaci in 3 replicates were used for each of the treatments and doses for estimating the relative expression of the target genes. The $B$. tabaci adults were crushed in $1 \mathrm{~mL}$ Trizol reagent within microcentrifuge tubes using a hand automizer. Total RNA was isolated as described earlier. Total RNA was quantified in a spectrophotometer (NanoDrop 2000, Thermo Fisher Scientific), and complementary DNA was synthesized using the FIREScript RT cDNA synthesis kit (Solis BioDyne, Tartu, Estonia) with $1.0 \mu \mathrm{g}$ template RNA for each set. The reaction mixture contained 1X RT reaction buffer, $1.0 \mu \mathrm{g}$ template RNA, $5.0 \mu \mathrm{M}$ oligo dT primer, $500 \mu \mathrm{M}$ dNTP mix, 10 units of FIREScript RT, and 1 unit of RiboGrip RNase inhibitor. The reverse transcription was carried out in a thermocycler (T100, Bio-Rad, CA, USA) at $42{ }^{\circ} \mathrm{C}$ for $60 \mathrm{~min}$, followed by enzyme inactivation at $85^{\circ} \mathrm{C}$ for $5 \mathrm{~min}$. The relative RT-qPCR assay was carried out in an Insta Q48M real-time PCR (Himedia, Mumbai, India) with $20 \mu \mathrm{L}$ reaction mixture containing $10 \mu \mathrm{L}$ of 1 X Maxima SYBR green master mix, $10 \mu \mathrm{M}$ ROX passive reference dye, 10 pmole each forward and reverse primer (AG204F-AG205R for $h s p 70$; AG283F-AG284R for fas2; and AG177F-AG178R for $\beta$-actin), and $2 \mu \mathrm{L}$ template cDNA. Thermal cycling was performed as initial denaturation at $94{ }^{\circ} \mathrm{C}$ for $5 \mathrm{~min}, 30$ cycles of $94{ }^{\circ} \mathrm{C}$ for $30 \mathrm{sec}, 56{ }^{\circ} \mathrm{C}$ for $30 \mathrm{~s}$, and $72{ }^{\circ} \mathrm{C}$ for $30 \mathrm{~s}$. Since SYBR Green I dye binds non-specifically to any double-stranded DNA, a dissociation or melting stage was carried out after every reaction to determine the specificity of the amplicons based on the melting curve. The RT-qPCR was performed with three biological and two technical replicates. The fold change in expression was normalized by excluding the changes in cycle threshold $\left(C_{T}\right)$ value of the endogenous control, $\beta$-actin. $\log _{2}$ fold change value was calculated, and relative expression of mRNA was determined by normalizing the $\log _{2} 2^{-\Delta \Delta C}$ T values of the dsRNA-treated samples with untreated control [48]. Statistical analysis and preparation of graphs were carried out in Microsoft Excel 2016.

\subsection{Quantification of Virus Copies in B. tabaci and Transmission of ChiLCV}

A portion of $B$. tabaci that survived post-feeding of dsRNA at $1.0,2.0$, and $3.0 \mu \mathrm{g} / \mathrm{mL}$ as described above was allowed to feed on ChiLCV-infected chilli plants (var. Preeti) for $24 \mathrm{~h}$. About 50 surviving $B$. tabaci in 3 replicates were used for each of the treatments and doses. ChiLCV copies acquired after $24 \mathrm{~h}$ feeding by dsRNA-exposed B. tabaci were estimated by absolute quantification in qPCR. A standard curve of ChiLCV was prepared using a clone of partial ChiLCV CP gene in a pJET1.0 vector (Thermo Fisher Scientific). Then, 10-fold serial dilutions $\left(5 \times 10^{2}\right.$ to $\left.5 \times 10^{-5} \mathrm{ng}\right)$ of linearized plasmid were amplified in qPCR as described below. The standard curve was prepared by plotting a linear regression curve with $\log _{10}$ DNA dilutions on the $X$-axis and $C_{T}$ values on the $Y$-axis. Three replicates of each dilution were used in preparing the standard curve. The statistical analysis and preparation of graphs were carried out in Microsoft Excel 2016.

After $24 \mathrm{~h}$ of acquisition, DNA was isolated using CTAB extraction buffer [49] from B. tabaci (30 per replicate) exposed to different doses $(1.0,2.0$, and $3.0 \mu \mathrm{g} / \mathrm{mL}$ ) of $h s p 70$ and fas 2 dsRNA separately. Briefly, B. tabaci adults were crushed in $1 \mathrm{~mL}$ CTAB extraction buffer (2\% CTAB, $100 \mathrm{mM}$ Tris- $\mathrm{HCl}$ pH 8.0, 20 mM EDTA pH 8.0, 1.4 M NaCl, and $2 \mu \mathrm{L}$ $\beta$-mercaptoethanol). The homogenate was heated in a dry bath at $65^{\circ} \mathrm{C}$ for $30 \mathrm{~min}$, and an equal volume of chloroform-isoamyl alcohol (24:1) was added to it. The mixture was vortexed for $<10 \mathrm{~s}$, incubated at room temperature, and centrifuged at $16,000 \times g$ for $15 \mathrm{~min}$. The upper aqueous phase was transferred to a fresh microcentrifuge tube, and an equal volume of isopropanol was added to precipitate the DNA. The solution was then centrifuged at $16,000 \times g$ for 15 min to pellet down the DNA and washed with $70 \%$ ethanol. The pellet was air-dried and dissolved in $30 \mu \mathrm{L}$ sterile distilled water followed by qPCR with the ChiLCV-specific primers AG149F and AG150R [47] (Table 1). The qPCR was carried out in an Insta Q48M real-time PCR with a $20 \mu \mathrm{L}$ reaction mixture as described above. Thermal cycling was performed as initial denaturation at $94{ }^{\circ} \mathrm{C}$ for $5 \mathrm{~min}, 30 \mathrm{cycles}$ of $94{ }^{\circ} \mathrm{C}$ for $30 \mathrm{~s}, 53{ }^{\circ} \mathrm{C}$ for $30 \mathrm{~s}$, and $72{ }^{\circ} \mathrm{C}$ for $30 \mathrm{~s}$. Melting curve analysis was carried out 
after each reaction to check the specificity of the amplicons. Each treatment was comprised of three biological and two technical replicates.

The mean $C_{T}$ values obtained in $\mathrm{qPCR}$ were fitted into the standard curve, and the resulting concentration was used for the calculation of virus copy number in Microsoft Excel 2016 using the following formula. Mean differences among the mean virus copies were separated by Tukey's test at a confidence interval of 95\% using XLSTAT 2014.5.03.

$$
\text { Virus copy number }(N)=\frac{\left(x \times 6.022 \times 10^{23}\right)}{\left(n \times 660 \times 10^{9}\right)}
$$

where $N=$ number of viral copies, $x=$ amount of amplicon in $\mathrm{ng}$, and $n=$ length of linearized plasmid DNA.

For the ChiLCV transmission experiment, B. tabaci surviving different doses (1.0, 2.0, and $3.0 \mu \mathrm{g} / \mathrm{mL}$ ) of $h s p 70$ and fas 2 dsRNA exposure were allowed to feed on ChiLCVinfected chilli plants for $24 \mathrm{~h}$. After acquisition feeding, they were released onto healthy chilli plants (var. Preeti) at the 4-6 leaf stage for $24 \mathrm{~h}$ of inoculation feeding and eliminated thereafter. Two adult females per plant were released. All the plants were maintained under insect-proof conditions and monitored for symptom development. ChiLCV infection in inoculated plants was confirmed by PCR 35 days post-inoculation. The transmission efficiency was calculated as the percent of plants infected by ChiLCV post- $24 \mathrm{~h}$ inoculation feeding by dsRNA-treated B. tabaci. B. tabaci without any exposure to dsRNA was used as a control. For each treatment, three biological replicates were used, and each replicate contained five plants. Tukey's test was used to test significant differences in transmission efficiency. $p$-values less than 0.05 were considered statistically significant.

\subsection{Topical Spray of hsp70 dsRNA under Contained Semi-Field Conditions}

A 10-fold higher dose of dsRNA $(30 \mu \mathrm{g} / \mathrm{mL})$ than the controlled condition assay was used to test its efficacy in a contained experiment under semi-field conditions where plants were covered by insect-proof nets and kept in the open air. The dsRNA was not artificially fed or applied directly on B. tabaci. Instead, naked $h s p 70$ dsRNA was topically sprayed on the ChiLCV-infected chilli plants (var. Preeti) like an insecticide in an insect-proof net house. Sterile distilled water was sprayed as a control. The plants were allowed to air-dry, and 100 virus-free B. tabaci adults were released on each dsRNA-treated ChiLCV-infected plant after $24 \mathrm{~h}$ of dsRNA spray. A total of 3 biological replicates, each containing 10 plants, were maintained. Percent mortality of $B$. tabaci $24 \mathrm{~h}$ after release on dsRNA-treated plants was calculated by normalizing the mean mortality in the control set. About 30 surviving B. tabaci in 3 replicates were used for determining the hsp70 mRNA levels in RT-qPCR as described above. The other portion of surviving $B$. tabaci was used for transmission of ChiLCV and was released onto 4-6 leaf stage healthy chilli plants (5 adults/plant) for $24 \mathrm{~h}$ of inoculation feeding. All the plants were maintained in insect-proof conditions and tested in PCR for ChiLCV-infection 35 days post-inoculation. A total of 5 biological replicates containing 12 plants each were used, and transmission efficiency was calculated as the percent of plants infected by ChiLCV. Tukey's test was performed to determine the significant differences in mean mortality and transmission efficiency among the categories at a confidence interval of $95 \%$.

\subsection{Stability of hsp70 dsRNA in Leaf Tissue}

To assess the stability of the dsRNA on the topically sprayed plants, apical leaf tissue was collected at 1, 3, 6, 24, and 48 h post-dsRNA spray in 3 replicates. Plants sprayed with sterile distilled water served as control. Total RNA was isolated from $100 \mathrm{mg}$ of plant tissues using Trizol reagent as described above. cDNA was synthesized using $h s p 70$ dsRNA-specific primer (AG137F and AG138R), and the presence of $h s p 70$ dsRNA was checked in PCR as described above. The experiment was repeated twice. 


\subsection{Persistent Efficacy of hsp70 dsRNA to Eradicate B. tabaci}

The persistency in eradicating B. tabaci population by topical spray of $h s p 70$ dsRNA was evaluated in a contained experiment under semi-field conditions. Chilli plants were topically sprayed with $h s p 70 \mathrm{dsRNA}$ at $30 \mu \mathrm{g} / \mathrm{mL}$. B. tabaci were released on the dsRNAtreated plants after $24 \mathrm{~h}$ of dsRNA spray. At every $24 \mathrm{~h}$, old B. tabaci adults were manually eliminated, and fresh adults were released to check the persistency in the efficacy of dsRNA. A total of 30 adults per plant were released each and every time, and percent mortality was recorded at $24 \mathrm{~h}$ post each release. This was continued until the mortality percentage decreased significantly. Upon significant decrease in mortality after the first spray, the second application of dsRNA was undertaken. The mortality percentage was recorded at $24 \mathrm{~h}$ intervals after the second spray, as described above. Sterile distilled water was sprayed in place of dsRNA as untreated control. Three biological replicates, each containing five plants, were used to calculate the percent mortality.

\section{Results}

\subsection{Characterization of B. tabaci and Begomovirus}

A homogeneous population of $B$. tabaci developed from a single adult female was characterized by sequencing the $\mathrm{mtCOI}$ gene. PCR amplification of $B$. tabaci $\mathrm{mtCOI}$ with C1-J-2195 and L2-N-3014 primers (Table 1) showed an expected amplicon of $\sim 860 \mathrm{bp}$ on an agarose gel. The nucleotide (nt) sequence showed $99.99 \%$ homology in BLASTn analysis with other B. tabaci Asia II 1 sequences in NCBI. The sequence can be retrieved using the GenBank Accession No. MT920041. Bayesian inference phylogeny considering genetic divergence cutoff of $4 \%$ revealed that the population belonged to the cryptic species $B$. tabaci Asia II 1 (data not presented).

The identity of the virus was confirmed by sequencing the DNA-A component from infected chilli plants. PCR amplification of the DNA-A using Begomo F and Begomo R primer produced a $2.7 \mathrm{~kb}$ product visualized on $1 \%$ agarose gel. Bidirectional sequencing of the cloned products produced a $2763 \mathrm{nt}$ sequence comprising complete DNA-A that showed $100 \%$ nucleotide identity to ChiLCV isolates upon BLASTn analysis. The sequence can be retrieved by GenBank Accession No. OM513903.

\subsection{Synthesis of dsRNA Targeting B. tabaci hsp70 and fas2}

A conserved $128 \mathrm{nt}-$ long (2416 to $2543 \mathrm{nt})$ fragment of the $h s p 70$ gene $(\sim 2.5 \mathrm{~kb})$ and a $150 \mathrm{nt}$-long (1085 to $1234 \mathrm{nt})$ fragment of the fas 2 gene $(\sim 1.4 \mathrm{~kb})$ of $B$. tabaci were selected for dsRNA designing (Figure 1a,b). In siRNA Wizard 3.1, the $128 \mathrm{nt}$-long B. tabaci hsp70 fragment produced a putative siRNA of $21 \mathrm{nt}$ (5'-GAUCCAUCCAUGCCGUUAAUC-3'). The $150 \mathrm{nt}$-long fas 2 fragment also yielded one putative siRNA of $21 \mathrm{nt}$ (5'-GGACGGAAGAAGGCAUAAUCA$\left.3^{\prime}\right)$. The dsRNA sequence was specific to $B$. tabaci, and no cross-reactivity was recorded with other organisms such as Homo sapiens, Mus musculus, Aves (taxid:8782), Lepidoptera (taxid:7088), Hymenoptera (taxid:7399), Formicidae (taxid:36668), and plants (taxid:3193) in BLAST analysis. PCR amplification of targeted B. tabaci hsp70 and fas2 fragments with AG137F-AG138R and AG283F-AG284R primer pairs gave single expected amplicons of $~ 130 \mathrm{bp}$ and $150 \mathrm{bp}$, respectively. The fragments were cloned between two T7 promoters of L4440 RNAi vector (Addgene 1654 provided by Andrew Fire, Carnegie Institution for Science, Washington, DC, USA). The recombinant plasmids were transformed into RNase III mutant Escherichia coli HT115 cells (provided by Caenorhabditis Genetics Center, Minneapolis, MN, USA). Total RNA isolated from recombinant E. coli HT115 cells and the dsRNA purified from total RNA using DNase I and RNase A were visualized in agarose gel electrophoresis (Figure 1c). The purified dsRNA of hsp70 and fas 2 produced single specific bands of $\sim 130 \mathrm{bp}$ and $150 \mathrm{bp}$ on $2 \%$ native agarose gel (Figure 1c). Upon bidirectional sequencing of the recombinant plasmids, both the sequences of hsp70 (Accession No. MZ158306) and fas2 (Accession No. MZ766125) showed 100\% homology with $B$. tabaci hsp70 and fas2, respectively. 


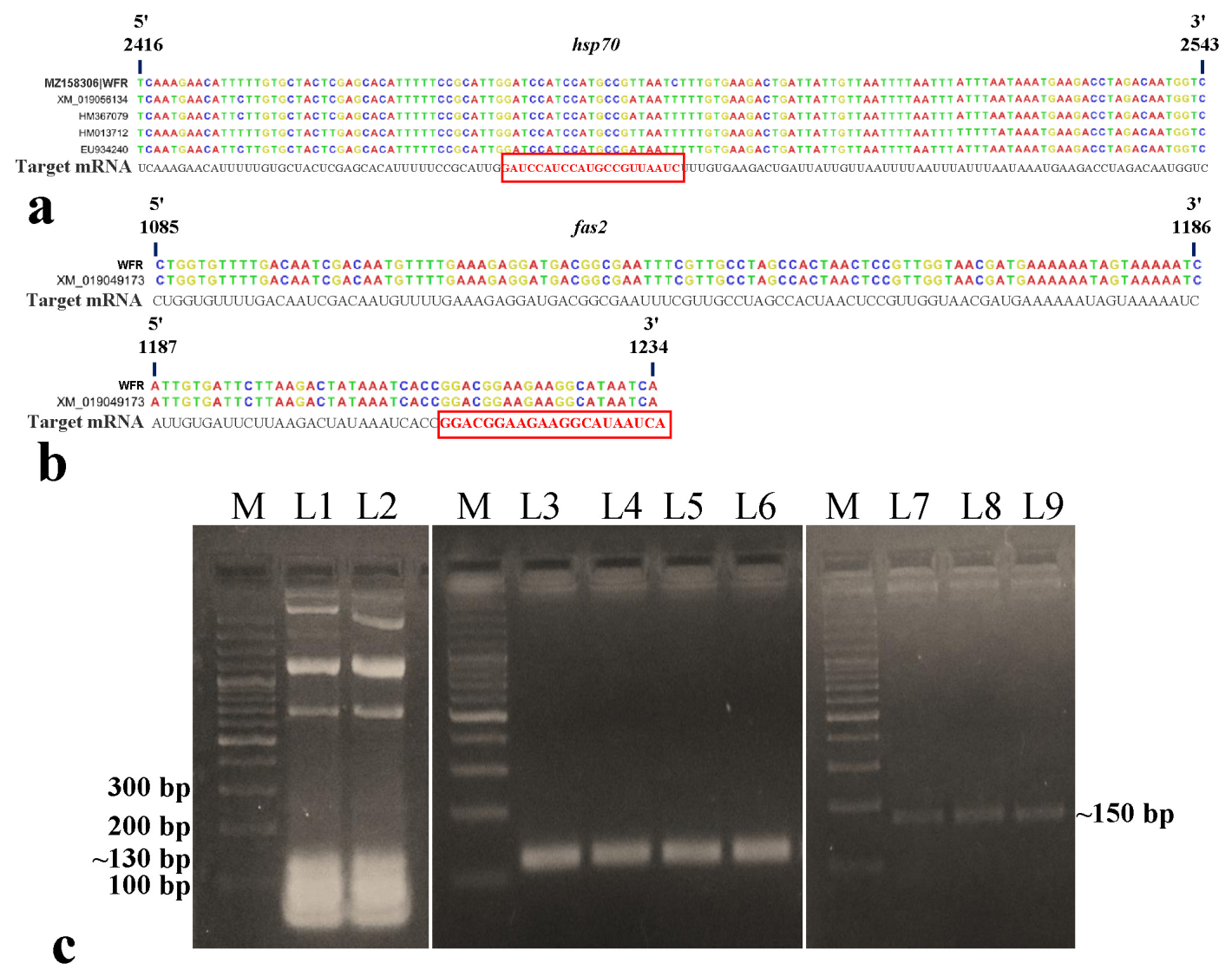

Figure 1. Designing and synthesis of dsRNA targeting Bemisia tabaci hsp70 and fas 2 mRNA. (a) A conserved region of 128 (2416 to 2543) nt of B. tabaci hsp70 was selected for designing dsRNA. The putative siRNA is marked within the red box. (b) A conserved region of 150 (1085 to 1234) nt of B. tabaci fas 2 was selected for designing dsRNA. The putative siRNA is marked within the red box. (c) Total RNA isolated from recombinant E. coli HT115 cells (L1-2); $h s p 70$ dsRNA purified from total RNA using DNase I and RNase A (L3-6); and fas2 dsRNA purified from total RNA using DNase I and RNase A (L7-9) on 2\% agarose gel stained with GoodView, $\mathrm{M}=100$ bp plus ladder.

\subsection{Effect of dsRNA on Mortality and mRNA Expression of B. tabaci under Controlled Conditions}

The efficacy of $h s p 70$ and fas 2 dsRNA was first evaluated under controlled laboratory conditions. Significantly higher mortality of $B$. tabaci adults was recorded in $h s p 70$ dsRNA than fas2 dsRNA when orally delivered under controlled laboratory conditions (Figure 2a). Mortality of $67.77 \%$ of $B$. tabaci was observed at $24 \mathrm{~h}$ upon feeding on $1.0 \mu \mathrm{g} / \mathrm{mL} \mathrm{hsp70} \mathrm{dsRNA.} \mathrm{The}$ mortality of $B$. tabaci significantly increased with an increase in dsRNA concentration. The mean mortality was $70.0 \%$ when $h s p 70$ dsRNA was fed to $B$. tabaci adults at $2.0 \mu \mathrm{g} / \mathrm{mL}$, and it increased significantly up to $82.22 \%$ at $3.0 \mu \mathrm{g} / \mathrm{mL} h s p 70$ dsRNA (Figure $2 \mathrm{~b}$ ). Oral delivery of fas 2 dsRNA at $1.0 \mu \mathrm{g} / \mathrm{mL}$ exhibited 39.33\% mean mortality after $24 \mathrm{~h}$ (Figure 2b). Significantly higher mortality (62 and 72\%) of $B$. tabaci adults was recorded when 2.0 and $3.0 \mu \mathrm{g} / \mathrm{mL}$ fas 2 dsRNA was orally delivered to $B$. tabaci under controlled laboratory conditions. At all doses, the mortality of $B$. tabaci post-fas 2 dsRNA exposure was significantly lower than the $h s p 70$ dsRNA at $p<0.05$. However, no morpho-deformities were observed in killed B. tabaci adults either with $h s p 70$ or fas 2 dsRNA.

RT-qPCR analysis showed that $h s p 70$ dsRNA significantly reduced the $h s p 70 \mathrm{mRNA}$ expression levels in treated B. tabaci. Hsp70 mRNA levels in adult B. tabaci were decreased by 5.43 -fold with respect to an endogenous control gene, $\beta$-actin, post- $24 \mathrm{~h}$ feeding on $h s p 70 \mathrm{dsRNA}$ (Figure 2c). The mRNA expression levels were significantly reduced with an increase in $h s p 70$ dsRNA concentration. An exposure to $h s p 70$ dsRNA at $2.0 \mu \mathrm{g} / \mathrm{mL}$ for $24 \mathrm{~h}$ significantly reduced 
the $h s p 70$ mRNA expression by 11.32-fold and up to 12.85 -fold when fed with $3.0 \mu \mathrm{g} / \mathrm{mL} h s p 70$ dsRNA. The fas 2 mRNA expression levels were declined by 5.48 -fold post- $24 \mathrm{~h}$ feeding on fas 2 dsRNA at $1.0 \mu \mathrm{g} / \mathrm{mL}$. The mRNA expression levels post-hsp70 and -fas 2 dsRNA feeding were almost similar at $1.0 \mu \mathrm{g} / \mathrm{mL}$. The mRNA expression levels were significantly reduced up to 8.53-fold with an increase in fas 2 dsRNA concentration. The reduction in mRNA expression level was significantly higher post- $h s p 70$ dsRNA feeding compared to fas 2 dsRNA at 2.0 and $3.0 \mu \mathrm{g} / \mathrm{mL}$. The primer pairs for $h s p 70$, fas 2 , and $\beta$-actin did not produce any secondary peaks in the RT-qPCR melting curve analysis that indicated the specificity of the reactions (Figure $2 \mathrm{~d}, \mathrm{e}$ ).
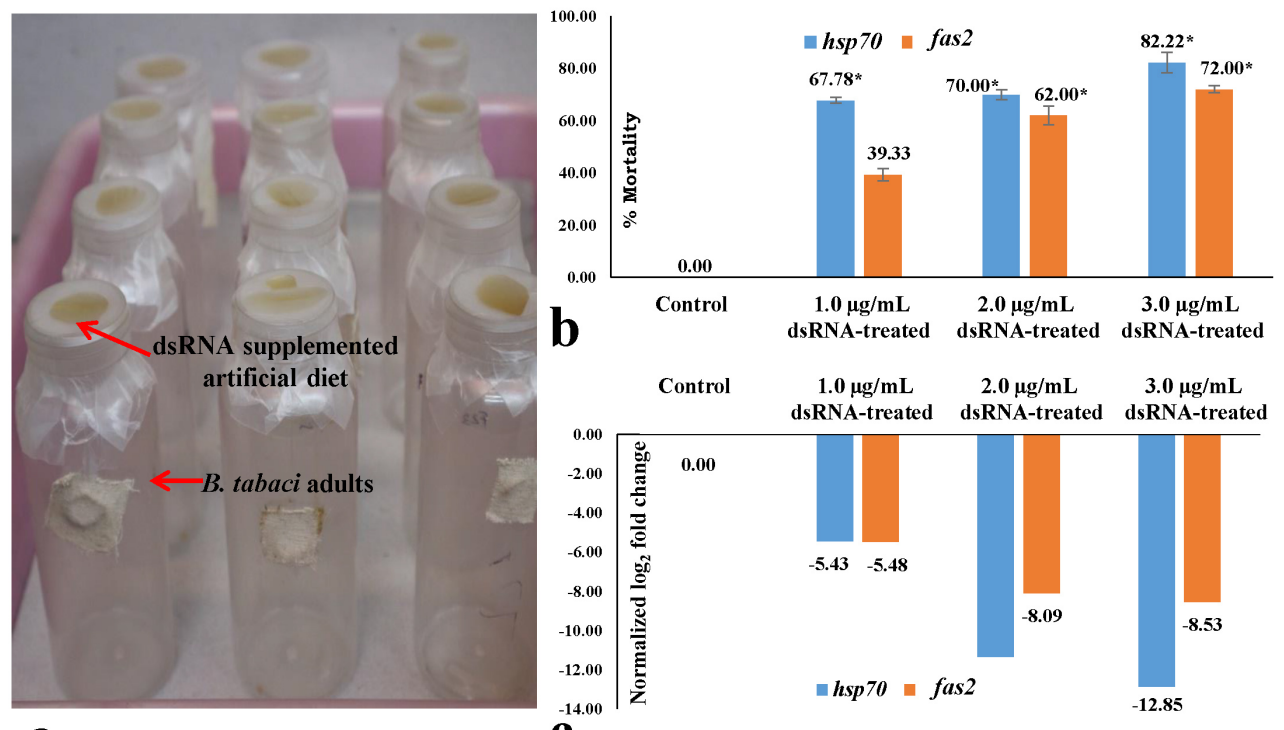

a

c
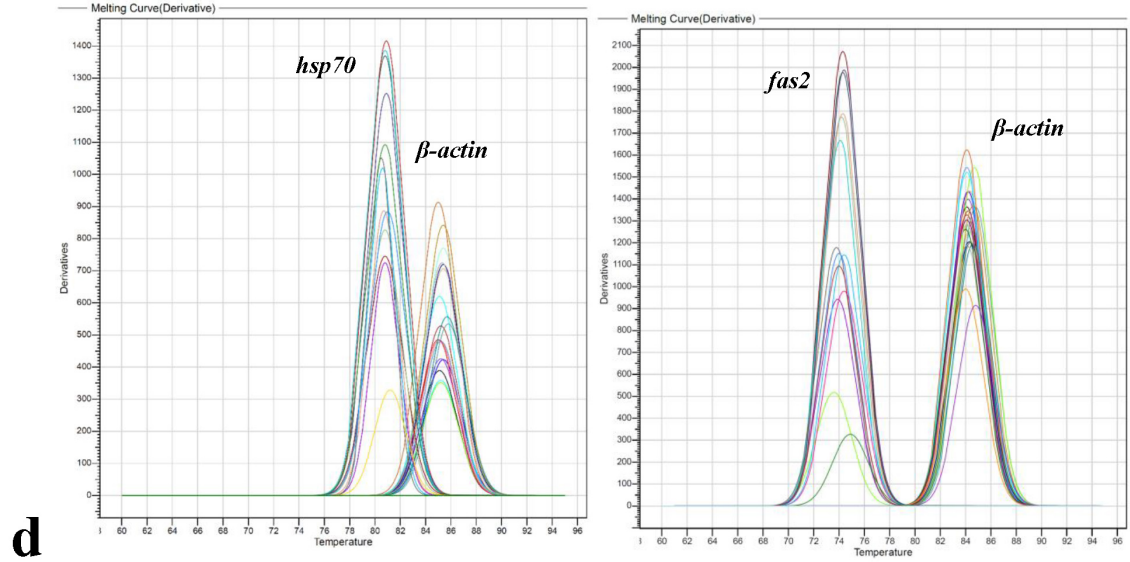

Figure 2. Effect of $h s p 70$ and fas 2 dsRNA delivered to Bemisia tabaci through artificial diet. (a) Artificial feeding setup for $B$. tabaci adults. The artificial diet was supplemented with different concentrations of dsRNA and sterile water (control). (b) Percent mortality of adult B. tabaci after $24 \mathrm{~h}$ of $h s p 70$ and fas2 dsRNA feeding at 1.0, 2.0, and $3.0 \mu \mathrm{g} / \mathrm{mL}$ in comparison to control. Values above each column are means of three replications. The experiment was repeated twice. The mean mortality was calculated by normalizing the mean mortality in the control set. The error bars are standard error of the mean (SEM). Mean denoted by an asterisk $\left(^{*}\right)$ indicates a significant difference $(p<0.05)$. (c) Normalized relative expression of $B$. tabaci hsp 70 and fas 2 mRNA after $24 \mathrm{~h}$ of dsRNA feeding in comparison to control. Relative quantification was done with respect to an endogenous control gene, $\beta$-actin. (d) Melting (dissociation) curves of $h s p 70$, fas2, and $\beta$-actin in RT-qPCR. The specific peaks of $h s p 70$, fas 2 , and $\beta$-actin amplicons without any secondary peaks indicated the specificity of the reactions. 


\subsection{Effect of dsRNA on Virus Acquisition and Transmission by B. tabaci under Controlled Conditions}

After $24 \mathrm{~h}$ of dsRNA feeding, the adult B. tabaci were allowed to feed on ChiLCV-infected plants for $24 \mathrm{~h}$. A standard curve of ChiLCV was prepared in qPCR using ten-fold dilutions of a clone of the partial ChiLCV CP gene. The standard curve of ChiLCV showed a coefficient of correlation $\left(R^{2}\right)$ of 0.995 and high amplification efficiency near to $100 \%$, indicating optimal conditions for absolute quantification (Figure 3a). The virus copies acquired by the B. tabaci were quantified by fitting the mean $\mathrm{C}_{\mathrm{T}}$ values obtained in qPCR into the standard curve. The specificity of the reactions was confirmed by a single peak at $81^{\circ} \mathrm{C}$ in the melting curve analysis of qPCR (Figure 3b). The virus copy number acquired by $h s p 70$ dsRNA-treated $B$. tabaci was significantly less than the untreated control. When $B$. tabaci was fed with sterile distilled water instead of $h s p 70$ dsRNA, the mean ChiLCV copy number was $2.22 \times 10^{15}$, whereas it decreased by 35.18 -fold $\left(6.31 \times 10^{13}\right.$ copies $)$ post-exposure to $h s p 70$ dsRNA at $1.0 \mu \mathrm{g} / \mathrm{mL}$ (Figure 3c). The virus copy number in treated B. tabaci further decreased with a gradual increase in $h s p 70$ dsRNA concentration. At $2.0 \mu \mathrm{g} / \mathrm{mL}$ hsp 70 dsRNA, ChiLCV copy numbers were $6.14 \times 10^{10}$ in B. tabaci i.e., $3.62 \times 10^{4}$-fold lower than the untreated control. The virus copies were undetectable in B. tabaci with a further increase in $h s p 70$ dsRNA concentration to $3.0 \mu \mathrm{g} / \mathrm{mL}$. The retention of ChiLCV might be completely ceased at a higher concentration of $h s p 70$ dsRNA or beyond the detection limit using qPCR. In contrast, the ChiLCV copy number acquired by fas 2 dsRNA-treated $B$. tabaci was significantly higher than the untreated control (Figure 3d). When B. tabaci was fed with sterile distilled water instead of fas 2 dsRNA, the mean ChiLCV copy number was $3.19 \times 10^{11}$, whereas the virus copies increased significantly by 139.18 -fold $\left(4.44 \times 10^{13}\right.$ copies $)$ at $1.0 \mu \mathrm{g} / \mathrm{mL}$ of fas $2 \mathrm{dsRNA}$ feeding. However, the mean virus copies were estimated to be $3.02 \times 10^{13}$ and $2.14 \times 10^{13}$ after exposure to 2.0 and $3.0 \mu \mathrm{g} / \mathrm{mL}$ fas 2 dsRNA, respectively. Although significantly higher numbers of virus copies were recorded in all fas 2 dsRNA doses compared to the control, higher doses of fas 2 dsRNA recorded a decline in virus copies compared to the lower doses. As the virus copies in B. tabaci increased post-fas 2 dsRNA feeding, it was not assessed further for inhibiting transmission of ChiLCV and topical application.

A similar pattern was recorded in the transmission of ChiLCV from infected to healthy chilli plants by $h s p 70$ dsRNA-fed B. tabaci. A $100 \%$ transmission of ChiLCV was recorded when $B$. tabaci was not exposed to hsp70 dsRNA in the control set. All the inoculated plants produced strong leaf curl and vein-clearing symptoms and tested ChiLCV positive in PCR. Although there was a significant decrease in ChiLCV copies in B. tabaci exposed to $1.0 \mu \mathrm{g} / \mathrm{mL}$ hsp $70 \mathrm{dsRNA}$, all the test plants were found to be infected with ChiLCV in PCR testing at 35 days post-inoculation. Probably even a lower concentration of ChiLCV in B. tabaci was sufficient to make $100 \%$ transmission. However, the severity of the leaf curl symptoms in inoculated plants was less than the untreated control. The transmission of ChiLCV was decreased to $40 \%$ when B. tabaci were fed with $2.0 \mu \mathrm{g} / \mathrm{mL} h s p 70$ dsRNA for $24 \mathrm{~h}$ (Figure 3e). The inoculated plants that tested positive in PCR produced mild leaf curl symptoms. Interestingly, there was no transmission of ChiLCV when B. tabaci was exposed to $3.0 \mu \mathrm{g} / \mathrm{mL}$ hsp $70 \mathrm{dsRNA}$. All the inoculated plants were without any leaf curl symptoms (Figure $3 \mathrm{f}$ ) and tested ChiLCV-free in PCR at 35 days post-inoculation. Probably virus transmission by B. tabaci completely inhibited at a higher concentration of $h s p 70$ dsRNA.

\subsection{Effect of Topical Spray of hsp70 dsRNA on Mortality and Virus Transmission by B. tabaci under Semi-Field Conditions}

In a contained experiment, the efficacy of topically sprayed naked $h s p 70$ dsRNA was tested under semi-field atmospheric conditions. The daily temperature fluctuated between $20^{\circ}$ and $35^{\circ} \mathrm{C}$ with $40-60 \%$ RH. dsRNA was not directly delivered to B. tabaci. Instead, it was sprayed on ChiLCV-infected chilli plants, and B. tabaci adults were released on the sprayed plants. Considering the exogenous degradation of dsRNA under natural atmospheric conditions, a ten-fold higher dose of dsRNA $(30 \mu \mathrm{g} / \mathrm{mL})$ than the controlled condition assay was used. A $67.77 \%$ mortality of adult $B$. tabaci was recorded post- $24 \mathrm{~h}$ exposure to dsRNA-treated plants (Figure 4a). A 4.6-fold decrease in $h s p 70$ mRNA expression levels 
of B. tabaci exposed to dsRNA-treated plants was also noted in RT-qPCR with respect to the endogenous control gene, $\beta$-actin (Figure $4 \mathrm{~b}$ ). Specific peaks of hsp70 and $\beta$-actin in the melting curve analysis without any secondary peaks confirmed the specificity of the reactions (Figure $4 \mathrm{c}$ ).

The surviving B. tabaci adults post-exposure to dsRNA-treated plants were further assessed for ChiLCV acquisition and transmission efficiency. A $1.84 \times 10^{8}$-fold decrease in ChiLCV copies was observed in B. tabaci post-24 h exposure to ChiLCV-infected plants that were sprayed with $h s p 70$ dsRNA at $30 \mu \mathrm{g} / \mathrm{mL}$ (Figure $4 \mathrm{~d}$ ). The melt curve of ChiLCV amplicon in qPCR produced specific peaks without any secondary peaks that confirmed the specificity of the reactions (Figure 4e). When a portion of the same B. tabaci population was used for inoculation of ChiLCV in healthy chilli plants, a 75\% decrease in transmission efficiency was confirmed in PCR test (Figure 4f) with no visible symptoms in the inoculated plants up to 50 days post-inoculation (Figure $4 \mathrm{~g}$ ). Probably, the virus titer was too low in inoculated plants to produce strong visible symptoms, whereas $100 \%$ transmission and severe leaf curl symptoms were noted in plants inoculated by unexposed B. tabaci. No transmission of ChiLCV was recorded in the plants mock-inoculated with untreated virus-free $B$. tabaci.

\subsection{Stability and Persistent Efficacy of hsp70 dsRNA in Eradicating B. tabaci Population}

The stability of $h s p 70$ dsRNA in leaf tissue was assessed through RT-PCR using $h s p 70$ specific primers. A specific amplicon of $\sim 130 \mathrm{bp}$ was produced from the leaf tissues collected 1, 3, and $6 \mathrm{~h}$ post-spray of $h s p 70$ dsRNA (Figure 5a).

To check the persistency in eradicating $B$. tabaci population by the topical spray of $h s p 70$ dsRNA under contained semi-field conditions, fresh $B$. tabaci adults were released on the dsRNA-treated chilli plants at $24 \mathrm{~h}$ intervals. After the first topical spray, mortality of $58.89 \%$ was recorded at 2 days. Significant mortality $(56.67 \%)$ persisted up to 8 days after the first spray (Figure $5 b$ ). The mortality decreased to $13.33 \%$ at 10 days after the first spray. A second spray was done on the 10th day to check the effect of multiple sprays. After the second topical spray of dsRNA, the mortality percentage again rose to $75 \%$ at two days. The highest mortality $(86.67 \%)$ of $B$. tabaci was recorded 4 days after the second spray. Significantly higher mortality was sustained up to 8 days after the second application and thereafter started decreasing. Overall, 2 consecutive sprays provided substantial protection against fresh releases of $B$. tabaci for up to 20 days. 


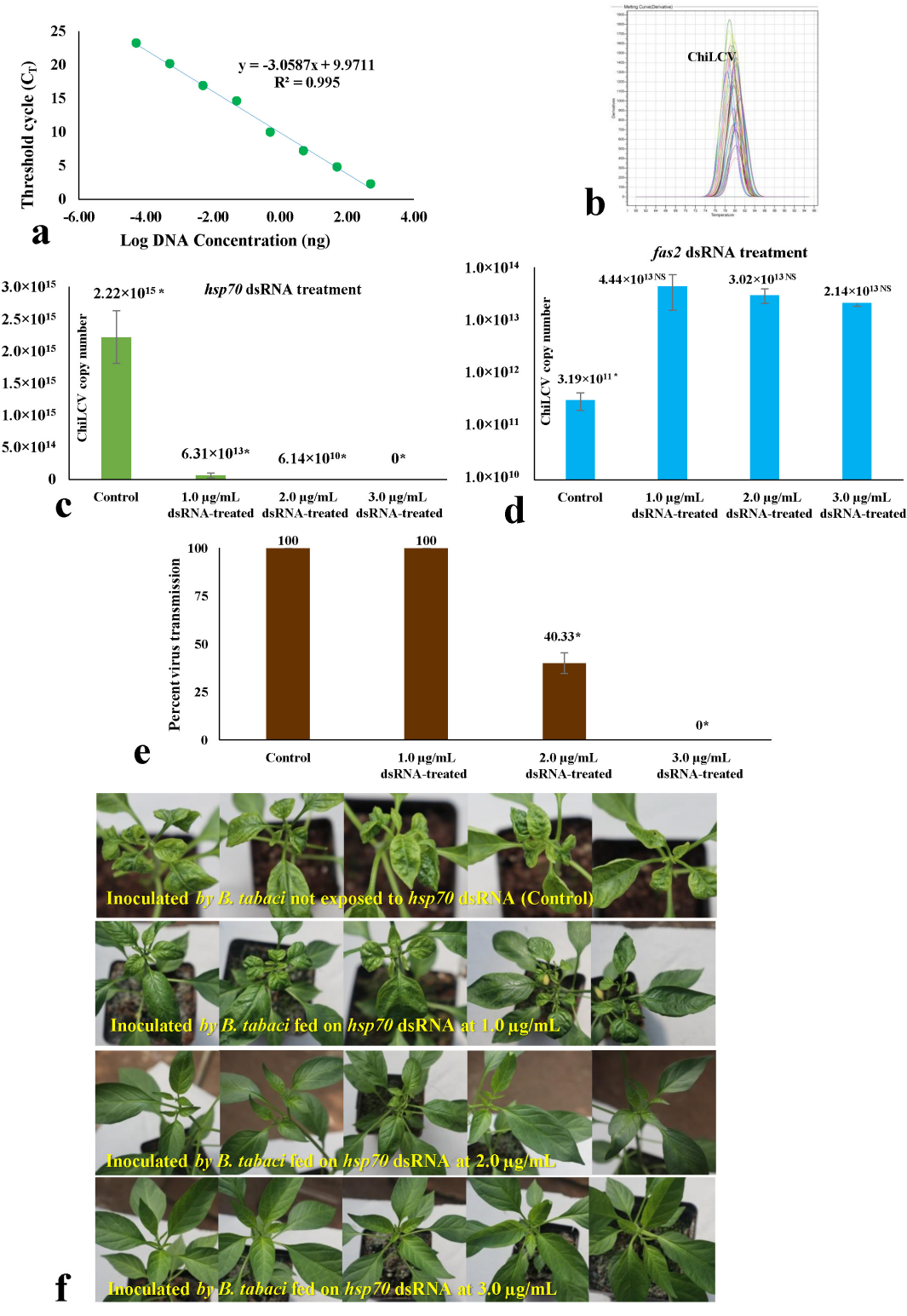

Figure 3. Effects of $h s p 70$ and fas 2 dsRNA in relation to ChiLCV acquisition by B. tabaci and respective involvement of $h s p 70$ dsRNA in transmission. (a) Standard curve of ChiLCV shows a linear relationship between $\log$ DNA concentrations in $n g$ on the $X$-axis and $\times$ values on the $Y$-axis. Each concentration was replicated thrice. The equation of the straight line and the coefficient of correlation $\left(R^{2}\right)$ are mentioned on the graph. (b) Melt curves of ChiLCV amplicon in qPCR analysis. A single specific peak at $81^{\circ} \mathrm{C}$ indicates the specificity of the reactions. (c) Mean ChiLCV copy numbers retained by $h s p 70$ dsRNAtreated B. tabaci after $24 \mathrm{~h}$ of acquisition feeding on ChiLCV-infected plants. (d) Mean ChiLCV copy numbers retained by fas 2 dsRNA-treated B. tabaci after $24 \mathrm{~h}$ of acquisition feeding on ChiLCV-infected plants. The error bars are standard error of the mean (SEM). Mean denoted by an asterisk $\left(^{*}\right)$ indicates a significant difference $(p<0.05)$. (e) Percent transmission of ChiLCV from infected to healthy chilli plants by hsp70 dsRNA-exposed B. tabaci. (f) Leaf curl symptoms on chilli (var. Preeti) plants 42 days after ChiLCV inoculation by $h s p 70$ dsRNA-fed B. tabaci. All the control plants produced typical leaf curl and vein clearing symptoms. All the plants inoculated by B. tabaci fed with $1.0 \mu \mathrm{g} / \mathrm{mL} h s p 70$ dsRNA were ChiLCV-positive in PCR but produced less severe symptoms of leaf curl than control. The transmission efficiency of $B$. tabaci fed with $2.0 \mu \mathrm{g} / \mathrm{mL} h s p 70$ dsRNA was $40 \%$; inoculated plants produced mild leaf curl symptoms. All the plants inoculated by B. tabaci fed with $3.0 \mu \mathrm{g} / \mathrm{mL} h s p 70$ dsRNA did not produce any symptoms and were ChiLCV-negative in PCR. For each treatment, three biological replicates were used and each replicate contained five plants. 

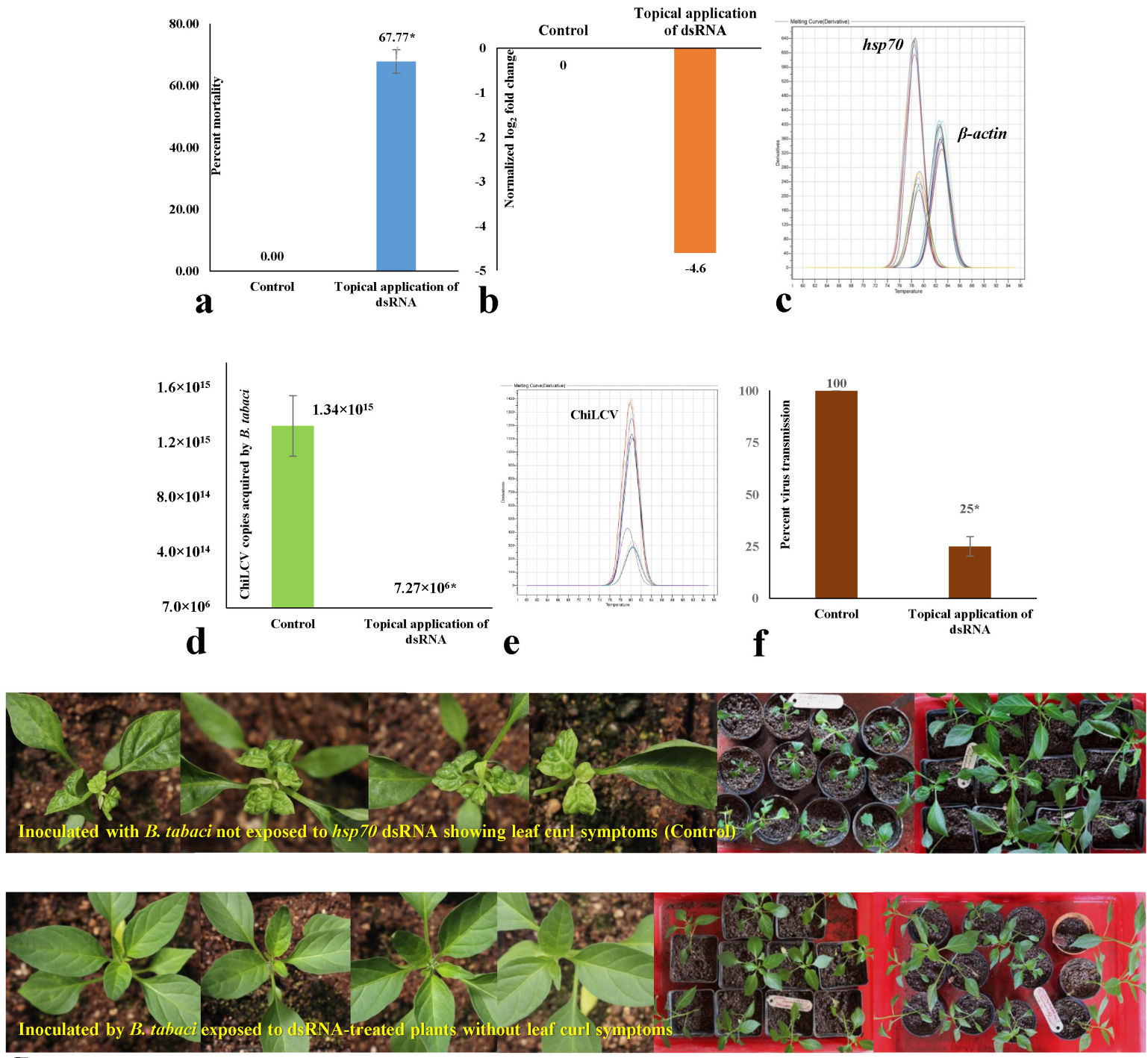

Figure 4. Effect of topical spray of naked $h s p 70$ dsRNA on mortality and ChiLCV transmission by Bemisia tabaci. dsRNA was not directly applied on B. tabaci. The naked hsp70 dsRNA was sprayed onto the foliage of ChiLCV-infected chilli plants like an insecticide at $30 \mu \mathrm{g} / \mathrm{mL}$. B. tabaci adults were released on the dsRNA-treated plants. (a) Percent mortality of adult B. tabaci post-24 h feeding on $h s p 70$ dsRNA-treated plants. The mortality in treated samples was calculated by normalizing the mortality in the control set. Values above each column are means of three replications. The error bars are standard error of the mean (SEM). Mean denoted by an asterisk $\left(^{*}\right)$ indicates a significant difference $(p<0.05)$. (b) Normalized relative expression of B. tabaci $h s p 70$ mRNA post- $24 \mathrm{~h}$ feeding on $h s p 70$ dsRNA-treated plants in comparison to control. Relative quantification was done with respect to an endogenous control gene, $\beta$-actin. (c) Melting (dissociation) curve analysis of RT-qPCR. The specific peaks of $h s p 70$ and $\beta$-actin amplicons without any secondary peaks indicated the specificity of the reactions. (d) Mean ChiLCV copies retained by B. tabaci post-24 h exposure to ChiLCV-infected plants that were topically sprayed with $h s p 70 \mathrm{dsRNA}$. (e) Melt curve of ChiLCV amplicon in qPCR analysis. The specific melting temperature for ChiLCV product was around $81{ }^{\circ} \mathrm{C}$. (f) Transmission of ChiLCV in healthy chilli plants by B. tabaci post-24 h exposure to $h s p 70$ dsRNA-treated plants. (g) Leaf curl symptoms on chilli (var. Preeti) plants after 42 days of ChiLCV inoculation by B. tabaci exposed to $h s p 70$ dsRNA-treated plants in comparison to control. All the control plants produced severe leaf curl and vein-clearing symptoms. Plants that were inoculated by $B$. tabaci exposed to $h s p 70$ dsRNA-treated chilli plants did not produce any symptoms up to 50 days post-inoculation. A total of 5 biological replicates containing 12 plants each were used. 

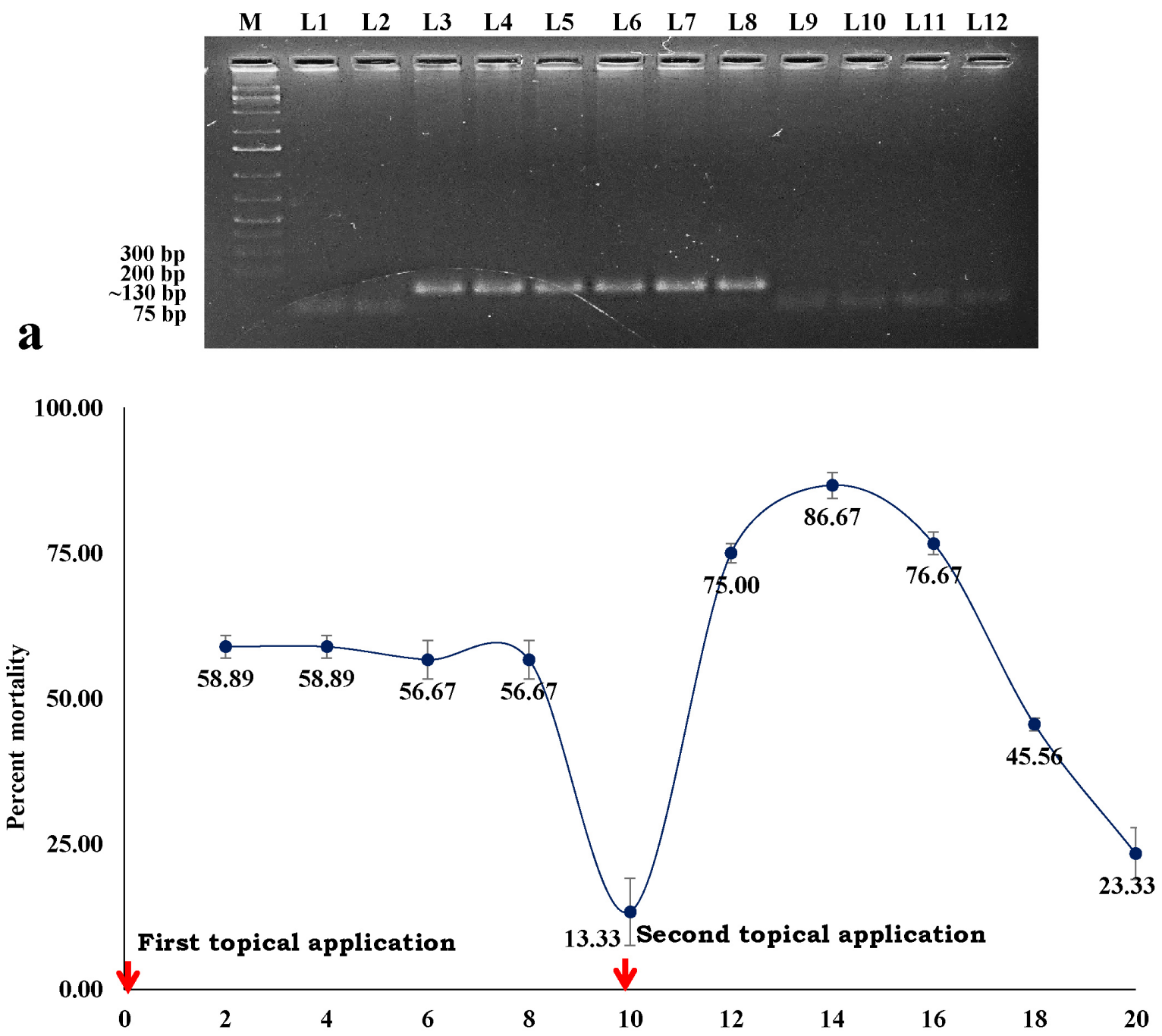

b

Days post-topical spraying of dsRNA

Figure 5. Stability and persistent efficacy of $h s p 70$ dsRNA. (a) Detection of dsRNA in RT-PCR. M: 100 bp plus DNA ladder, L1-2: untreated control, RT-PCR amplicons of dsRNA in leaf tissue $1 \mathrm{~h}$ (L3-4), $3 \mathrm{~h}$ (L5-6), $6 \mathrm{~h}$ (L7-8), $24 \mathrm{~h}$ (L9-10), and $48 \mathrm{~h}$ (L11-12) post-application. (b) Mean percent mortality of adult B. tabaci exposed to $h s p 70$ dsRNA-treated chilli plants. A total of 30 B. tabaci adults per plant were released at $24 \mathrm{~h}$ intervals, and mean percent mortality was calculated by normalizing the mortality in the control set. Values below each dot and bars on the dots indicate mean percent mortality of three replications and standard error of the mean (SEM), respectively. Each replicate contained five plants. Red arrows indicate the dates of spraying.

\section{Discussion}

Several management strategies have been adopted around the world, with insecticides as the core component for the management of the B. tabaci-ChiLCV complex. However, the use of chemical insecticides has led to several detrimental effects like the development of insecticide-resistant $B$. tabaci population, destruction of beneficial organisms, environmental contamination, and health hazards [50-52]. There is a need for an alternative eco-friendly approach in managing $B$. tabaci-ChiLCV. RNAi or post-transcriptional gene silencing (PTGS) was introduced to study the functionality of specific genes through knocking down target gene mRNA [53]. However, in no time, it gained recognition as a potential therapeutic agent to control insect pests [54,55]. With the advancements in next-generation sequencing 
and transcriptomics technology, several genes have been identified as potential targets to control B. tabaci and its viruses [33-40,56-58]. However, most studies are limited to the oral feeding of the dsRNA to $B$. tabaci through artificial diet or genetic modification of the host plants $[40,43,59,60]$. None of these RNAi molecules have been tested for their efficacy or found effective under field conditions, limiting their large-scale adoption. RNAi using dsRNA constructs is not suitable for field conditions due to rapid degradation and a lack of reliable delivery agents. In the present study, for the first time, we demonstrated the efficacy of a naked dsRNA against an insect pest by spray-on application under semi-field conditions. The dsRNA construct targeting the $h s p 70$ gene of $B$. tabaci not only induced mortality in B. tabaci but also inhibited the transmission of ChiLCV from infected to healthy chilli plants by $B$. tabaci.

Hsp70 and fas2 were found to be significantly upregulated in viruliferous $B$. tabaci along with several other genes $[30,35,57]$. Gene regulatory networking showed these genes were enriched with higher degrees of interactions [35]. Hsp70 transcripts increased upon ingestion of tomato yellow leaf curl virus (TYLCV) and squash leaf curl virus (SLCV) in DNA microarray [31]. The role of $h s p 70$ in begomovirus transmission is well studied [30,31,57,60,61]. TYLCV $\mathrm{CP}$ and Hsp70 interacted in vitro and co-localized within midgut epithelial cells [30,31]. The fas 2 mRNA expression level was upregulated in viruliferous B. tabaci by 2.6 and 4.518 -fold in the RNA-Seq and RT-qPCR assay, respectively. The Fas2 orthologue in mammals (NCAM) is known to serve as a receptor for the rabies virus [39]. Hence, we targeted to knock down these two genes, $h s p 70$ and fas2, to induce immunity to ChiLCV infection in B. tabaci. Conserved 128 and $150 \mathrm{nt}$ stretches in the $h s p 70$ and fas2 genes, respectively, were found to be specific to $B$. tabaci without any cross-reactivity to humans, mice, birds, butterflies, bees, ants, and plants. Each produced a putative siRNA of $21 \mathrm{nt}$. dsRNA was synthesized by in vivo transcription to harvest large quantities of dsRNA at a low cost. Bacterially expressed dsRNA is economical and convenient, as reported in several studies [62-64]. Before evaluating the efficacy of topically sprayed dsRNA, we tested it under controlled laboratory conditions. Both $h s p 70$ and fas 2 dsRNA were orally delivered to $B$. tabaci adults by mixing with an artificial diet in a feeding setup. Similar types of artificial feeding setup were reported to be efficient in the oral delivery of dsRNA [40-42]. A significant knockdown of the B. tabaci population was recorded at $24 \mathrm{~h}$, which gradually increased with an increase in dsRNA concentration. Up to $82.22 \%$ mortality of B. tabaci was recorded after $24 \mathrm{~h}$ feeding on $3.0 \mu \mathrm{g} / \mathrm{mL}$ hsp $70 \mathrm{dsRNA}$. Similarly, fas 2 dsRNA at $3.0 \mu \mathrm{g} / \mathrm{mL}$ caused $72 \%$ mortality of B. tabaci $24 \mathrm{~h}$ post-feeding. The dsRNA exposure downregulated the $h s p 70$ and fas 2 mRNA expressions by 12.85- and 8.53-fold, respectively. The expression of an endogenous control gene was unregulated post-dsRNA exposure. This indicated the specificity of the dsRNA constructs to target genes. Hsp belongs to the multifunctional molecular chaperone family involved in the aggregation of damaged proteins, transportation, assembly, and disassembly of multi-structured units under stressed conditions $[36,65]$. The mortality of $B$. tabaci post-dsRNA feeding may be due to the loss of function via depletion of $h s p 70$ mRNA, which might interrupt the normal biological processes in $B$. tabaci. In Drosophila melanogaster, Fas2 is involved in synaptic development and growth [37,38]. It is also known to function in intracellular signaling pathways that involve mitogen-activated protein kinase (MAPK) and regulate intracellular calcium levels [38]. However, the function of fas 2 in B. tabaci is uncharacterized. Kanakala et al. [60] reported twisting of wings in B. tabaci upon silencing $h s p 70$. However, we did not record any morphological deformities in treated B. tabaci. Hsp70 and fas 2 might not be involved in the morphogenesis of B. tabaci, or longer exposure to dsRNA is required to produce such deformities.

The persistent circulative transmission of ChiLCV by B. tabaci indicates that the virus particles reach the midgut after ingestion. The virions cross the midgut barrier to become circulative in the hemolymph and accumulate in the primary salivary glands [30]. Hsp70, along with other molecular chaperones, plays an important role in the translocation of viral proteins besides its function in viral replication, assembly, and disassembly of the viral proteins inside the hosts [66-70]. Hsp70 has been found to interact with TYLCV CP in vitro and co-localize within midgut epithelial cells [31]. In the present study, oral delivery of 
hsp70 dsRNA significantly reduced ChiLCV copies in B. tabaci Asia II 1 and its transmission to healthy chilli plants as well. The resistance to ChiLCV in B. tabaci was enhanced at higher concentrations of $h s p 70$ dsRNA. ChiLCV copies in B. tabaci were imperceptible when $B$. tabaci fed on $3 \mu \mathrm{g} / \mathrm{mL} h s p 70$ dsRNA for $24 \mathrm{~h}$. The transmission of ChiLCV from infected to healthy plants by B. tabaci Asia II 1 was completely inhibited at $3 \mu \mathrm{g} / \mathrm{mL} h s p 70$ dsRNA treatment under controlled conditions. Our findings are consistent with Kanakala et al. [60], who reported the deleterious effect of $B$. tabaci hsp70 dsRNA on TYLCV transmission. The TYLCV titer decreased in B. tabaci Middle East Asia Minor 1 (MEAM 1) after feeding on hsp70 dsRNA-expressing tomato plants. Transmission of TYLCV also dropped by $12 \%$ post-silencing of $h s p 70$ [60]. In the present study, the inability of B. tabaci Asia II 1 to retain and transmit ChiLCV post-silencing of $h s p 70$ indicates that it might also play an important function in ChiLCV infection. However, Gotz et al. [31] reported an increase in TYLCV transmission upon blocking Hsp70 by anti-Hsp70 antibody in B. tabaci MEAM1. It was hypothesized that the Hsp70-TYLCV interaction mediates the degradation of virions. Downregulation of $h s p 70, h s p 40$, and $h s p 20$ resulted in 3.1-, 1.5-, and 1.2-fold increases in cotton leaf curl virus ( $\mathrm{CLCuV}$ ) titer within $B$. tabaci. Significantly increased transmission efficiency of CLCuV was noted in B. tabaci Asia II 1 when $h s p 70$ was silenced [61]. The difference may be due to the variation in virus species and $B$. tabaci cryptic species. The interactions of $B$. tabaci with begomoviruses are not conserved and alter with cryptic species of B. tabaci and begomovirus species [71,72]. B. tabaci MEAM1 has two genes (Bta03000 and Bta02903) annotated as $h s p 70$, and their amino acid sequences differ by $97.55 \%$ [56]. They might also exhibit differential responses to begomovirus infection. Unlike $h s p 70$ dsRNA treatment, an increase in the ChiLCV copies in B. tabaci was recorded post-fas 2 dsRNA feeding. The Fas2 orthologue in mammals (NCAM) is known to serve as a receptor for the rabies virus. Although NCAM promotes the penetration of the virus in cells, it suppresses virus replication via induction of Interferon- $B$ [39], which is mainly involved in innate immunity against viral infection. Upregulation of fas 2 transcripts in $B$. tabaci post-ChiLCV infection might be due to the innate immune response against the virus infection [35]. We hypothesized that fas 2 has a negative regulatory role in ChiLCV infection, and thus, knocking down fas 2 increased the virus titer in $\mathrm{B}$. tabaci. Hence, silencing fas 2 was not considered to induce resistance to ChiLCV despite its efficacy in eradicating B. tabaci.

Although RNAi has emerged as a promising alternative to suppress crop pests [73,74], there are limitations in the application of dsRNA as a 'spray-on' technology for field use. Reduced stability in the extracellular environments of dsRNA contributes to poor RNAi response. The naked dsRNA quickly degrades in higher temperatures and UV radiation under natural environmental conditions. Besides, several insect species, mainly lepidopteran insects, have been observed to be refractory to RNAi due to degradation and poor intracellular transport of exogenous dsRNA $[75,76]$. Nucleases are the major factors limiting the efficacy of dsRNA [75-77]. In the first phase of the study, hsp70 dsRNA showed high potential in eradicating $B$. tabaci and inhibiting ChiLCV transmission. In the next phase, the dsRNA construct was assessed under natural environmental conditions by spraying like an insecticide. Adult B. tabaci are highly mobile, so spraying on adult flies was not preferred. Hence, naked $h s p 70$ dsRNA without any delivery agent was topically sprayed onto the foliage of the ChiLCV-infected chilli plant under contained semi-field conditions. B. tabaci adults were released on the dsRNA-sprayed plants to evaluate the dsRNA's efficacy in eradicating $B$. tabaci and inhibiting the transmission of ChiLCV. Considering the extracellular degradation of dsRNA and delivery through the host plant, a 10-fold higher dose than the controlled assay was used for topical application. A $67.77 \%$ mortality with a 4.6-fold decrease in $h s p 70$ mRNA levels in B. tabaci exposed to the dsRNA-sprayed plants was noted after $24 \mathrm{~h}$ of release. Further, $1.84 \times 10^{8}$-fold decreased ChiLCV copies and $75 \%$ reduced transmission of ChiLCV indicated the efficiency of topically sprayed hsp70 dsRNA in managing both the virus and its vector. Although the efficacy of topically applied naked dsRNA against plant viruses is known [78-80], this is the first evidence of its efficacy against a hemipteran insect like $B$. tabaci. 
Topical application of dsRNA could provide resistance for 12 to 21 days against plant viruses [78,80-82]. In the present study, dsRNA was detected in the leaf tissues up to $6 \mathrm{~h}$ post-application. Significant mortality of $B$. tabaci on the treated plants persisted up to 8 days and was further sustained up to 20 days with a second spray on the 10th day. Protection of the plants during the early growth stage is crucial in the management of begomoviruses. Begomovirus infection at a 5-leaf stage in tomatoes reduced yield by $95 \%$ [83]. Infection of ChiLCV at the seedling stage leads to a considerable reduction in plant height, internodal length, and fruiting. Hence, a 20-day shield by 2 consecutive sprays of naked hsp70 dsRNA would protect the crucial phase of crop growth from the invasion of B. tabaci and ChiLCV and reduce yield losses. The foliar spray of $h s p 70 \mathrm{dsRNA}$ was effective under semi-field conditions where the daily temperature fluctuated between $20-35{ }^{\circ} \mathrm{C}$ with $40-60 \% \mathrm{RH}$. The efficacy and persistency of topically sprayed naked dsRNA at a wide temperature range endorse its potentiality for field uses as a spray-on technology.

\section{Conclusions}

In conclusion, the spray-on application of naked dsRNA targeting $h s p 70$ of $B$. tabaci provides resistance to both ChiLCV and its vector, B. tabaci. This is a novel alternative to hazardous insecticides and may be further assessed on a large scale for its efficacy under real-field conditions.

Author Contributions: A.G. conceived and designed the research. P.C. conducted the experiments, recorded experimental data, and performed analysis. A.G. reviewed the data. P.C. wrote the draft manuscript. A.G. wrote and edited the final manuscript. All authors have read and agreed to the published version of the manuscript.

Funding: This study was supported by the IARI and Department of Biotechnology, Government of India (BT/PR25296/NER/95/1116/2017).

Institutional Review Board Statement: Not applicable.

Informed Consent Statement: Not applicable.

Data Availability Statement: Sequences have been deposited to GenBank under accession numbers MT920041, MW399222, MZ158306, MZ766125, and OM513903.

Acknowledgments: The support received from IARI, New Delhi, and the Department of Biotechnology, Government of India is thankfully acknowledged.

Conflicts of Interest: The authors declare that they have no conflict of interest.

Ethical Approval: The research meets ethical guidelines and adheres to the legal requirements of the study country. This research does not involve human subjects.

\section{References}

1. Oliveira, M.R.V.; Henneberry, T.J.; Anderson, P. History, Current Status, and Collaborative Research Projects for Bemisia tabaci. Crop Prot. 2001, 20, 709-723. [CrossRef]

2. Chowda-Reddy, R.; Kirankumar, M.; Seal, S.E.; Muniyappa, V.; Valand, G.B.; Govindappa, M.; Colvin, J. Bemisia tabaci Phylogenetic Groups in India and the Relative Transmission Efficacy of Tomato Leaf Curl Bangalore Virus by an Indigenous and an Exotic Population. J. Integr. Agric. 2012, 11, 235-248. [CrossRef]

3. Legarrea, S.; Barman, A.; Marchant, W.; Diffie, S.; Srinivasan, R. Temporal Effects of a Begomovirus Infection and Host Plant Resistance on the Preference and Development of an Insect Vector, Bemisia tabaci, and Implications for Epidemics. PLoS ONE 2015, 10, e0142114. [CrossRef]

4. Mugerwa, H.; Seal, S.; Wang, H.L.; Patel, M.V.; Kabaalu, R.; Omongo, C.A.; Alicai, T.; Tairo, F.; Ndunguru, J.; Sseruwagi, P.; et al. African Ancestry of New World, Bemisia tabaci-Whitefly Species. Sci. Rep. 2018, 8, 2734. [CrossRef]

5. Jiu, M.; Hu, J.; Wang, L.J;; Dong, J.F.; Song, Y.Q.; Sun, H.Z. Cryptic Species Identification and Composition of Bemisia tabaci (Hemiptera: Aleyrodidae) Complex in Henan Province, China. J. Insect Sci. 2017, 17, 78-84. [CrossRef]

6. Rehman, M.; Chakraborty, P.; Tanti, B.; Mandal, B.; Ghosh, A. Occurrence of a New Cryptic Species of Bemisia tabaci (Hemiptera: Aleyrodidae): An Updated Record of Cryptic Diversity in India. Phytoparasitica 2021, 49, 869-882. [CrossRef]

7. Byrne, D.N.; Bellows, T.S. Whitefly Biology. Annu. Rev. Entomol. 1991, 36, 431-457. [CrossRef]

8. Jones, D.R. Plant Viruses Transmitted by Whiteflies. Eur. J. Plant Pathol. 2003, 109, 195-219. [CrossRef] 
9. Navas-Castillo, J.; Fiallo-Olivé, E.; Sánchez-Campos, S. Emerging Virus Diseases Transmitted by Whiteflies. Annu. Rev. Phytopathol. 2011, 49, 219-248. [CrossRef]

10. Brown, J.K.; Zerbini, F.M.; Navas-Castillo, J.; Moriones, E.; Ramos-Sobrinho, R.; Silva, J.C.; Fiallo-Olivé, E.; Briddon, R.W.; Hernández-Zepeda, C.; Idris, A.; et al. Revision of Begomovirus Taxonomy Based on Pairwise Sequence Comparisons. Arch. Virol. 2015, 160, 1593-1619. [CrossRef]

11. Orfanidou, C.G.; Pappi, P.G.; Efthimiou, K.E.; Katis, N.I.; Maliogka, V.I. Transmission of Tomato Chlorosis Virus (ToCV) by Bemisia tabaci Biotype Q and Evaluation of Four Weed Species as Viral Sources. Plant Dis. 2016, 100, 2043-2049. [CrossRef] [PubMed]

12. Zanardo, L.G.; Carvalho, C.M. Cowpea mild mottle virus (Carlavirus, Betaflexiviridae): A review. Trop. Plant Pathol. 2017, 42, 417-430. [CrossRef]

13. Ghosh, S.; Kanakala, S.; Lebedev, G.; Kontsedalov, S.; Silverman, D.; Alon, T.; Mor, N.; Sela, N.; Luria, N.; Dombrovsky, A.; et al. Transmission of a New Polerovirus Infecting Pepper by the Whitefly Bemisia tabaci. J. Virol. 2019, 93, e00488-19. [CrossRef] [PubMed]

14. Costa, T.M.; Inoue-Nagata, A.K.; Vida, A.H.; Ribeiro, S.G.; Nagata, T. The recombinant isolate of cucurbit aphid-borne yellows virus from Brazil is a polerovirus transmitted by whiteflies. Plant Pathol. 2020, 69, 1042-1050. [CrossRef]

15. Pinheiro-Lima, B.; Pereira-Carvalho, R.C.; Alves-Freitas, D.M.T.; Kitajima, E.W.; Vidal, A.H.; Lacorte, C.; Godinho, M.T.; Fontenele, R.S.; Faria, J.C.; Abreu, E.F.M.; et al. Transmission of the Bean-Associated Cytorhabdovirus by the Whitefly Bemisia tabaci MEAM1. Viruses 2020, 12, 1028. [CrossRef]

16. Cornejo-Franco, J.F.; Reyes-Proaño, E.G.; Mollov, D.; Mowery, J.; Quito-Avila, D.F. Transmission and Pathogenicity of Papaya Virus E: Insights from an Experimental Papaya Orchard. Plant Dis. 2022, 2017, 2467940. [CrossRef]

17. Mansoor, S.; Briddon, R.W.; Zafar, Y.; Stanley, J. Geminivirus Disease Complexes: An Emerging Threat. Trends Plant Sci. 2003, 8 , 128-134. [CrossRef]

18. Briddon, R.W.; Patil, B.L.; Bagewadi, B.; Nawaz-ul-Rehman, M.S.; Fauquet, C.M. Distinct Evolutionary Histories of the DNA-A and DNA-B Components of Bipartite Begomoviruses. BMC. Evol. Biol. 2010, 10, 97. [CrossRef]

19. Saeed, S.T.; Samad, A. Emerging Threats of Begomoviruses to the Cultivation of Medicinal and Aromatic Crops and Their Management Strategies. Virus Dis. 2017, 28, 1-17. [CrossRef]

20. CABI. Capsicum Annuum (Bell Pepper). Invasive Species Compendium. Available online: https://www.cabi.org/isc/datasheet/ 15784 (accessed on 13 April 2021).

21. Oraon, U.B.; Tarafdar, J. Occurrence and distribution of chilli leaf curl complex disease in West Bengal. Biomed. J. Sci. Tech. Res. 2018, 3, 3515-3519. [CrossRef]

22. Kumar, Y.; Hallan, V.; Zaidi, A.A. Chilli Leaf Curl Palampur Virus Is a Distinct Begomovirus species Associated with a Betasatellite. Plant Pathol. 2011, 60, 1040-1047. [CrossRef]

23. Khan, A.J.; Akhtar, S.; Al-Zaidi, A.M.; Singh, A.K.; Briddon, R.W. Genetic Diversity and Distribution of a Distinct Strain of Chili Leaf Curl Virus and Associated Betasatellite Infecting Tomato and Pepper in Oman. Virus Res. 2013, 177, 87-97. [CrossRef] [PubMed]

24. Senanayake, D.M.J.B.; Mandal, B.; Lodha, S.; Varma, A. First Report of Chilli Leaf Curl Virus Affecting Chilli in India. Plant Pathol. 2007, 56, 343. [CrossRef]

25. Senanayake, D.M.J.B.; Jayasinghe, J.E.; Shilpi, S.; Wasala, S.K.; Mandal, B. A New Begomovirus-Betasatellite Complex Is Associated with Chilli Leaf Curl Disease in Sri Lanka. Virus Genes 2013, 46, 128-139. [CrossRef]

26. Thakur, H.; Jindal, S.K.; Sharma, A.; Dhaliwal, M.S. Chilli Leaf Curl Virus Disease: A Serious Threat for Chilli Cultivation. J. Plant Dis. Prot. 2018, 125, 239-249. [CrossRef]

27. Menike, G.D.N.; De Costa, D.M. Variation of Field Symptoms and Molecular Diversity of the Virus Isolates Associated with Chilli Leaf Curl Complex in Different Agroecological Regions of Sri Lanka. Trop. Agric. Res. 2017, 28, 144. [CrossRef]

28. Geley, S.; Müller, C. RNAi: Ancient Mechanism with a Promising Future. Exp. Gerontol. 2004, 39, 985-998. [CrossRef]

29. Rosen, R.; Kanakala, S.; Kliot, A.; Cathrin Pakkianathan, B.; Farich, B.A.; Santana-Magal, N.; Elimelech, M.; Kontsedalov, S.; Lebedev, G.; Cilia, M.; et al. Persistent, Circulative Transmission of Begomoviruses by Whitefly Vectors. Curr. Opin. Virol. 2015, 15, 1-8. [CrossRef]

30. Czosnek, H.; Hariton-Shalev, A.; Sobol, I.; Gorovits, R.; Ghanim, M. The Incredible Journey of Begomoviruses in Their Whitefly Vector. Viruses 2017, 9, 273. [CrossRef]

31. Götz, M.; Popovski, S.; Kollenberg, M.; Gorovits, R.; Brown, J.K.; Cicero, J.M.; Czosnek, H.; Winter, S.; Ghanim, M. Implication of Bemisia tabaci Heat Shock protein 70 in Begomovirus-Whitefly Interactions. J. Virol. 2012, 86, 13241-13252. [CrossRef]

32. Kanakala, S.; Ghanim, M. Implication of the Whitefly Bemisia tabaci Cyclophilin B Protein in the Transmission of Tomato Yellow Leaf Curl Virus. Front. Plant Sci. 2016, 7, 1702. [CrossRef] [PubMed]

33. Rana, V.S.; Popli, S.; Saurav, G.K.; Raina, H.S.; Chaubey, R.; Ramamurthy, V.V.; Rajagopal, R. A Bemisia tabaci Midgut Protein Interacts with Begomoviruses and Plays a Role in Virus Transmission. Cell. Microbiol. 2016, 18, 663-678. [CrossRef] [PubMed]

34. Wang, Z.Z.; Shi, M.; Huang, Y.C.; Wang, X.W.; Stanley, D.; Chen, X.X. A Peptidoglycan Recognition Protein Acts in Whitefly (Bemisia tabaci) Immunity and Involves in Begomovirus Acquisition. Sci. Rep. 2016, 6, 37806. [CrossRef] [PubMed]

35. Nekkanti, A. Changes in Transcriptome of Whitefly (Bemisia Tabaci Gennadius) Associated with Begomovirus Infection. Master's Thesis, Post Graduate School, ICAR-Indian Agricultural Research Insitute, New Delhi, India, 2021; p. 66. 
36. Hartl, F.U.; Hayer-Hartl, M. Molecular Chaperones in the Cytosol: From Nascent Chain to Folded Protein. Science 2002, 295, 1852-1858. [CrossRef]

37. Packard, M.; Mathew, D.; Budnik, V. FASt Remodeling of Synapses in Drosophila. Curr. Opin. Neurobiol. 2003, 13, 527-534 [CrossRef]

38. Kristiansen, L.V.; Hortsch, M. Fasciclin II: The NCAM Ortholog in Drosophila melanogaster. Adv. Exp. Med. Biol. 2010, 663, 387-401. [CrossRef]

39. Hotta, K.; Motoi, Y.; Okutani, A.; Kaku, Y.; Noguchi, A.; Inoue, S.; Yamada, A. Role of GPI-Anchored NCAM-120 in Rabies Virus Infection. Microbes Infect. 2007, 9, 167-174. [CrossRef]

40. Upadhyay, S.K.; Chandrashekar, K.; Thakur, N.; Verma, P.C.; Borgio, J.F.; Singh, P.K.; Tuli, R. RNA interference for the Control of Whiteflies (Bemisia tabaci) by Oral Route. J. Biosci. 2011, 36, 153-161. [CrossRef]

41. Li, H.; Guan, R.; Guo, H.; Miao, X. New Insights into an RNAi Approach for Plant Defense Against Piercing-Sucking and Stem-Borer Insect Pests. Plant Cell Environ. 2015, 38, 2277-2285. [CrossRef]

42. Vyas, M.; Raza, A.; Ali, M.Y.; Ashraf, M.A.; Mansoor, S.; Shahid, A.A.; Brown, J.K. Knock Down of Whitefly Gut Gene Expression and Mortality by Orally Delivered Gut Gene-Specific dsRNAs. PLoS ONE 2017, 12, e0168921. [CrossRef]

43. Bar, L.; Czosnek, H.; Sobol, I.; Ghanim, M.; Hariton Shalev, A. Down Regulation of Dystrophin Expression in Pupae of the Whitefly Bemisia tabaci Inhibits the Emergence of Adults. Insect Mol. Biol. 2019, 28, 662-675. [CrossRef]

44. Akhter, A.; Qazi, J.; Saeed, M.; Mansoor, S. A Severe Leaf Curl Disease on Chilies in Pakistan Is Associated with Multiple Begomovirus Components. Plant Dis. 2009, 93, 962. [CrossRef] [PubMed]

45. Ahn, S.J.; Donahue, K.; Koh, Y.; Martin, R.R.; Choi, M.Y. Microbial-Based Double-Stranded RNA Production to Develop CostEffective RNA interference Application for Insect Pest Management. Int. J. Insect Sci. 2019, 11, 1179543319840323. [CrossRef] [PubMed]

46. Simon, C.; Frati, F.; Beckenbach, A.; Crespi, B.; Liu, H.; Flook, P. Evolution, Weighting, and Phylogenetic Utility of Mitochondrial Gene Sequences and a Compilation of Conserved Polymerase Chain Reaction Primers. Ann. Entomol. Soc. Am. 1994, 87, 651-701. [CrossRef]

47. Roy, B.; Chakraborty, P.; Ghosh, A. How many begomovirus copies are acquired and inoculated by its vector, whitefly (Bemisia tabaci) during feeding? PLOS ONE 2021, 16, e0258933. [CrossRef] [PubMed]

48. Livak, K.J.; Schmittgen, T.D. Analysis of Relative Gene Expression Data Using Real-Time Quantitative PCR and the $2^{-\Delta \Delta \mathrm{C}_{\mathrm{T}}}$ Method. Methods 2001, 25, 402-408. [CrossRef]

49. Doyle, J.J.; Doyle, J.L. Isolation of Plant DNA from Fresh Tissue. Focus 1990, 12, 13-15.

50. Abdullah, N.M.M.; Singh, J.; Sohal, B.S. Behavioral Hormoligosis in Oviposition Preference of Bemisia tabaci on Cotton. Pestic. Biochem. Physiol. 2006, 84, 10-16. [CrossRef]

51. Bacci, L.; Crespo, A.L.; Galvan, T.L.; Pereira, E.J.; Picanço, M.C.; Silva, G.A.; Chediak, M. Toxicity of Insecticides to the Sweetpotato Whitefly (Hemiptera: Aleyrodidae) and Its Natural Enemies. Pest Manag. Sci. 2007, 63, 699-706. [CrossRef]

52. Houndété, T.A.; Kétoh, G.K.; Hema, O.S.; Brévault, T.; Glitho, I.A.; Martin, T. Insecticide Resistance in Field Populations of Bemisia tabaci (Hemiptera: Aleyrodidae) in West Africa. Pest Manag. Sci. 2010, 66, 1181-1185. [CrossRef]

53. Sen, G.L.; Blau, H.M. A Brief History of RNAi: The Silence of the Genes. FASEB J. 2006, 20, 1293-1299. [CrossRef] [PubMed]

54. Baum, J.A.; Bogaert, T.; Clinton, W.; Heck, G.R.; Feldmann, P.; Ilagan, O.; Johnson, S.; Plaetinck, G.; Munyikwa, T.; Pleau, M.; et al. Control of Coleopteran Insect Pests Through RNA interference. Nat. Biotechnol. 2007, 25, 1322-1326. [CrossRef] [PubMed]

55. Huvenne, H.; Smagghe, G. Mechanisms of dsRNA Uptake in Insects and Potential of RNAi for Pest Control: A Review. J. Insect Physiol. 2010, 56, 227-235. [CrossRef] [PubMed]

56. Chen, W.; Hasegawa, D.K.; Kaur, N.; Kliot, A.; Pinheiro, P.V.; Luan, J.; Stensmyr, M.C.; Zheng, Y.; Liu, W.; Sun, H.; et al. The Draft Genome of Whitefly Bemisia tabaci MEAM1, a Global Crop Pest, Provides Novel Insights into Virus Transmission, Host Adaptation, and Insecticide Resistance. BMC Biol. 2016, 14, 110. [CrossRef]

57. Ding, T.B.; Li, J.; Chen, E.H.; Niu, J.Z.; Chu, D. Transcriptome Profiling of the Whitefly Bemisia tabaci MED in Response to Single Infection of Tomato Yellow Leaf Curl Virus, Tomato Chlorosis Virus, and Their Co-Infection. Front. Physiol. 2019, 10, 302. [CrossRef]

58. Hussain, S.; Farooq, M.; Malik, H.J.; Amin, I.; Scheffler, B.E.; Scheffler, J.A.; Liu, S.S.; Mansoor, S. Whole Genome Sequencing of Asia II 1 Species of Whitefly Reveals That Genes Involved in Virus Transmission and Insecticide Resistance Have Genetic Variances Between Asia II 1 and MEAM1 Species. BMC Genom. 2019, 20, 507. [CrossRef]

59. Grover, S.; Jindal, V.; Banta, G.; Taning, C.N.T.; Smagghe, G.; Christiaens, O. Potential of RNA interference in the Study and Management of the Whitefly, Bemisia tabaci. Arch. Insect Biochem. Physiol. 2019, 100, e21522. [CrossRef]

60. Kanakala, S.; Kontsedalov, S.; Lebedev, G.; Ghanim, M. Plant-Mediated Silencing of the Whitefly Bemisia tabaci Cyclophilin B and Heat Shock protein 70 Impairs Insect Development and Virus Transmission. Front. Physiol. 2019, 10, 557. [CrossRef]

61. Kaur, R.; Gupta, M.; Singh, S.; Joshi, N.; Sharma, A. Enhancing RNAi Efficiency to Decipher the Functional Response of Potential Genes in Bemisia tabaci Asia II-1 (Gennadius) Through dsRNA Feeding Assays. Front. Physiol. 2020, 11, 123. [CrossRef]

62. Tenllado, F.; Martínez-García, B.; Vargas, M.; Díaz-Ruíz, J.R. Crude Extracts of Bacterially Expressed dsRNA Can Be Used to Protect Plants Against Virus Infections. BMC Biotechnol. 2003, 3, 3. [CrossRef]

63. Leelesh, R.S.; Rieske, L.K. Oral Ingestion of Bacterially Expressed dsRNA Can Silence Genes and Cause Mortality in a Highly Invasive, Tree-Killing Pest, the Emerald Ash Borer. Insects 2020, 11, 440. [CrossRef] [PubMed] 
64. Cherenko, V.A.; Filipenko, E.A.; Golubeva, T.S. Silencing of Nicotiana Benthamiana Phytoendesaturase Using dsRNA Synthesized In Vivo. In IOP Conference Series: Earth and Environmental Science; IOP Publishing: Bristol, UK, 2021; p. 723. [CrossRef]

65. Gregersen, N.; Bross, P.; Andrese, B.S.; Pedersen, C.B.; Corydon, T.J.; Bolund, L. The Role of Chaperone-Assisted Folding and Quality Control in Inborn Errors of Metabolism: Protein Folding Disorders. J. Inherit. Metab. Dis. 2001, 24, 189-212. [CrossRef] [PubMed]

66. Mayer, M.P. Recruitment of Hsp70 Chaperones: A Crucial Part of Viral Survival Strategies. Rev. Physiol. Biochem. Pharmacol. 2005, 153, 1-46. [CrossRef]

67. Serva, S.; Nagy, P.D. Proteomics Analysis of the Tombusvirus Replicase: Hsp70 Molecular Chaperone Is Associated with the Replicase and Enhances Viral RNA Replication. J. Virol. 2006, 80, 2162-2169. [CrossRef]

68. Ivanovic, T.; Agosto, M.A.; Chandran, K.; Nibert, M.L. A Role for Molecular Chaperone Hsc70 in Reovirus Outer Capsid Disassembly. J. Biol. Chem. 2007, 282, 12210-12219. [CrossRef] [PubMed]

69. Czosnek, H. Tomato Yellow Leaf Curl Virus Disease. In Management, Molecular Biology, Breeding for Resistance; Czosnek, H., Ed.; Springer: Berlin/Heidelberg, Germany, 2007; Volume 440. [CrossRef]

70. Gorovits, R.; Moshe, A.; Ghanim, M.; Czosnek, H. Recruitment of the Host Plant Heat Shock protein 70 by Tomato Yellow Leaf Curl Virus Coat Protein Is Required for Virus Infection. PLoS ONE 2013, 8, e70280. [CrossRef]

71. Jiu, M.; Zhou, X.P.; Liu, S.S. Acquisition and Transmission of Tobacco Curly Shoot Virus by the B Biotype of the Whitefly, Bemisia tabaci. Acta Phytophylacica Sin. 2006, 33, 168-172. [CrossRef]

72. Guo, X.J.; Feng, J.N. Comparisons of Expression Levels of Heat Shock Proteins (hsp70 and hsp90) from Anaphothrips obscurus (Thysanoptera: Thripidae) in Polymorphic Adults Exposed to Different Heat Shock Treatments. J. Insect Sci. 2018, 18, 15. [CrossRef]

73. Palli, S.R. RNA interference in Colorado Potato Beetle: Steps Toward Development of dsRNA as a Commercial Insecticide. Curr. Opin. Insect Sci. 2014, 6, 1-8. [CrossRef]

74. Zotti, M.J.; Smagghe, G. RNAi Technology for Insect Management and Protection of Beneficial Insects from Diseases: Lessons, Challenges and Risk Assessments. Neotrop. Entomol. 2015, 44, 197-213. [CrossRef]

75. Garbutt, J.S.; Reynolds, S.E. Induction of RNA interference Genes by Double-Stranded RNA. Implications for Susceptibility to RNA interference. Insect Biochem. Mol. Biol. 2012, 42, 621-628. [CrossRef] [PubMed]

76. Shukla, J.N.; Kalsi, M.; Sethi, A.; Narva, K.E.; Fishilevich, E.; Singh, S.; Mogilicherla, K.; Palli, S.R. Reduced Stability and Intracellular Transport of dsRNA Contribute to Poor RNAi Response in Lepidopteran Insects. RNA Biol. 2016, 13, 656-669. [CrossRef] [PubMed]

77. Christiaens, O.; Whyard, S.; Vélez, A.M.; Smagghe, G. Double-Stranded RNA Technology to Control Insect Pests: Current Status and Challenges. Front. Plant Sci. 2020, 11, 451. [CrossRef] [PubMed]

78. Namgial, T.; Kaldis, A.; Chakraborty, S.; Voloudakis, A. Topical Application of Double-Stranded RNA Molecules Containing Sequences of Tomato Leaf Curl Virus and Cucumber Mosaic Virus Confers Protection Against the Cognate Viruses. Physiol. Mol. Plant Pathol. 2019, 108, 101432. [CrossRef]

79. Worrall, E.A.; Bravo-Cazar, A.; Nilon, A.T.; Fletcher, S.J.; Robinson, K.E.; Carr, J.P.; Mitter, N. Exogenous Application of RNAiInducing Double-Stranded RNA Inhibits Aphid-Mediated Transmission of a Plant Virus. Front. Plant Sci. 2019, 10, 265. [CrossRef] [PubMed]

80. Konakalla, N.C.; Bag, S.; Deraniyagala, A.S.; Culbreath, A.K.; Pappu, H.R. Induction of Plant Resistance in Tobacco (Nicotiana tabacum) Against Tomato Spotted Wilt Orthotospovirus Through Foliar Application of dsRNA. Viruses 2021, 13, 662. [CrossRef]

81. Konakalla, N.C.; Kaldis, A.; Berbati, M.; Masarapu, H.; Voloudakis, A.E. Exogenous Application of Double-Stranded RNA Molecules from TMV p126 and CP Genes Confers Resistance Against TMV in Tobacco. Planta 2016, 244, 961-969. [CrossRef]

82. Kaldis, A.; Berbati, M.; Melita, O.; Reppa, C.; Holeva, M.; Otten, P.; Voloudakis, A. Exogenously Applied dsRNA Molecules Deriving from the Zucchini Yellow Mosaic Virus (ZYMV) Genome Move Systemically and Protect Cucurbits Against ZYMV. Mol. Plant Pathol. 2018, 19, 883-895. [CrossRef]

83. Kumar, P.; Kumar, M. Leaf Curl Disease: A Significant Constraint in the Production of Tomato in India. In Advances in Plant Pathology; Kumatu, J.N., Ed.; IntechOpen: London, UK, 2018; pp. 93-101. [CrossRef] 